Florida International University FIU Digital Commons

7-13-2012

\title{
The Function of Cyclo(Phe-Pro) in Gene Expression of Vibrio Harveyi
}

Bruce Milburn

Florida International University, bmilburn2@gmail.com

DOI: $10.25148 /$ etd.FI12080618

Follow this and additional works at: https://digitalcommons.fiu.edu/etd

\section{Recommended Citation}

Milburn, Bruce, "The Function of Cyclo(Phe-Pro) in Gene Expression of Vibrio Harveyi" (2012). FIU Electronic Theses and Dissertations. 695.

https://digitalcommons.fiu.edu/etd/695

This work is brought to you for free and open access by the University Graduate School at FIU Digital Commons. It has been accepted for inclusion in FIU Electronic Theses and Dissertations by an authorized administrator of FIU Digital Commons. For more information, please contact dcc@fiu.edu. 


\title{
FLORIDA INTERNATIONAL UNIVERSITY
}

Miami, Florida

\section{THE FUNCTION OF CYCLIC-PHENYLALANINE-PROLINE (cFP) IN GENE EXPRESSION OF VIBRIO HARVEYI}

\author{
A thesis submitted in partial fulfillment of \\ the requirements for the degree of \\ MASTER OF SCIENCE \\ in \\ BIOLOGY \\ by
}

Bruce Milburn 


\section{To: Dean Kenneth G. Furton}

College of Arts and Sciences

This thesis, written by Bruce Milburn, and entitled The Function of Cyclo(Phe-Pro) in Gene Expression of Vibrio harveyi, having been approved in respect to style and intellectual content, is referred to you for judgment.

We have read this thesis and recommend that it be approved.

Miroslav Gantar

DeEtta Kay Mills

John Makemson, Major Professor

Date of Defense: July 13, 2012

The thesis of Bruce Milburn is approved.

Dean Kenneth G. Furton

College of Arts and Sciences

Dean Lakshmi N. Reddi University Graduate School

Florida International University, 2012 


\section{ACKNOWLEDGEMENTS}

I wish to thank the members of my committee for all of their help during my time in graduate school. Dr. DeEtta Mills and Dr. Miroslav Gantar have been very accommodating and helpful through the process of developing my thesis and provided much needed insight. I would like to especially thank my major professor, Dr. John Makemson, for his patience, careful instruction, and for providing me the history of our field while bestowing upon me its skills. Without the help of these scientists this work would not have been possible. 


\section{ABSTRACT OF THE THESIS \\ THE FUNCTION OF CYCLO(PHE-PRO) IN GENE EXPRESSION OF VIBRIO HARVEYI}

by

Bruce Milburn

Florida International University, 2012

Miami, Florida

Professor John Makemson, Major Professor

Vibrio harveyi is a bioluminescent bacterium and the organism in which quorum sensing was discovered. It was recently found that a class of molecules, cyclic dipeptides, may be a new kind of quorum sensing signal that may affect other species in the genus. The purpose of this study was to determine if $V$. harveyi produced one of these molecules, cyclo(Phe-Pro) or cFP, and the effects it has on bioluminescence, growth and gene expression. Electrospray Mass Spectrometry was used to detect cFP, and it was found. While growth and gene expression were not significantly affected by cFP, bioluminescence was slightly induced at low concentrations. It appears that $V$. harveyi does not produce $\mathrm{cFP}$ and it does not significantly affect the luminescence quorum sensing controlled genes, and is most likely not a true signal, in $V$. harveyi. 


\section{TABLE OF CONTENTS}

CHAPTER

PAGE

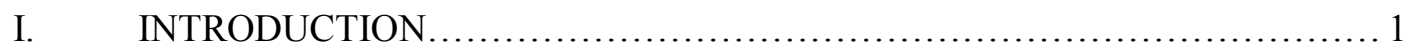

II. MATERIALS AND METHODS......................................

III. RESULTS ................................................................. 10

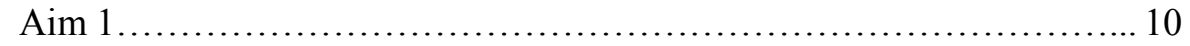

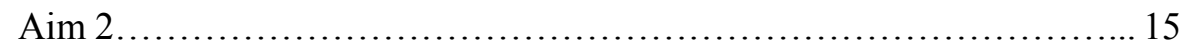

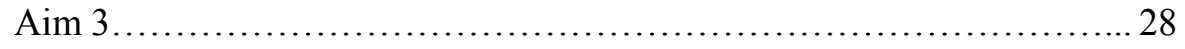

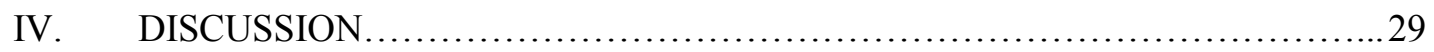

V. CONCLUSIONS ......................................................... 31

LIST OF REFERENCES................................................. 32

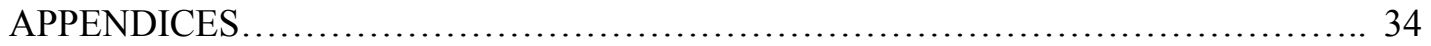




\section{LIST OF FIGURES}

FIGURE

PAGE

1. MASS SPECTRA OF UNINOCULATED AB MEDIA................................ 11

2. MASS SPECTRA OF $V$. HARVEYI MAV IN AB MEDIA........................... 12

3A. GROWTH CURVE OF $V$. HARVEYI BB120 (HIGH CFP CONCENTRATION)......18

3B. GROWTH CURVE OF $V$. HARVEYI BB120 (LOW CFP CONCENTRATION).......19

4A. MONOD PLOT OF $V$. HARVEYI BB120 (HIGH CFP CONCENTRATION)..........20

4B. MONOD PLOT OF $V$. HARVEYI BB120 (LOW CFP CONCENTRATION)...........21

5. MONOD PLOT OF $V$. HARVEYI MAV ............................................ 22

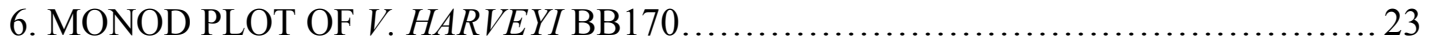

7. MONOD PLOT OF $V$. HARVEYI BB152 ..................................... 24

8. MONOD PLOT OF $V$. HARVEYI BB886........................................ 25

9A. GROWTH CURVE OF $V$. HARVEYI BB120 IN MINIMAL MEDIA..................26

9B. MONOD PLOT OF $V$. HARVEYI BB120 IN MINIMAL MEDIA..................... 27

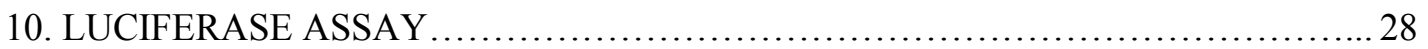




\section{Introduction}

Most species capable of bioluminescence are found in the oceans and range from bacteria to fish; the most recognizable terrestrial bioluminescent organism is the firefly. There are a variety of functions for bioluminescence in nature: attracting prey, evading predators or communicating (Haddock et al. 2010, Meighen 1991).

Bacteria are responsible for some of the bioluminescence of fish and invertebrates. In many fish and other marine organisms, bacteria may be localized into a specialized light organ where they produce the light. In these symbiotic relationships the bacteria provide light in exchange for the safety and nutrients provided by the larger organism (Haddock et al. 2010). Not all bioluminescent bacteria are symbionts however; many exist planktonically, as free-living organisms in seawater, or as pathogens (Meighen 1991). Most bioluminescent bacteria fall into one of five main genera: Vibrio, Photobacterium, Photorhabdus, Alivibrio and Shewanella. All of these genera include Gram-negative species, and all are found mostly in marine environments except for Photorhabdus (Meighen 1991, Wimpee et al. 1991).

The general mechanism of bioluminescence is basically the same in all organisms that use it, but there are specific differences depending upon species. The reaction involves a luciferase, an enzyme that catalyzes light production, and a luciferin, the substrate of the reaction and the molecule which produces an excited state that depopulates releasing light. Depending on the species, the luciferins may be very specific molecules and these molecules are highly conserved amongst species. This contrasts with the luciferases, which vary (orthologous and paralogous) between species (Haddock et al. 2010). In bacteria, the luciferin is not specific to the light reaction; they are substrates $\left(\mathrm{FMNH}_{2}\right.$, aliphatic aldehyde, and oxygen) common to many cellular processes so they do not need specific manufacturing. The mechanism for the light producing reaction in bacteria involves a reduced flavin $\left(\mathrm{FMNH}_{2}\right)$, a long chain aliphatic 
aldehyde (R-CHO), and molecular oxygen as substrates for luciferase. The luciferase binds oxygen to the reduced flavin producing a 4a-peroxy-flavin that is oxidized after adding the fatty aldehyde to form a relatively stable intermediate whose slow decay emits light (hv). The overall reaction is:

$$
\mathrm{FMNH}_{2}+\mathrm{R}-\mathrm{CHO}+\mathrm{O}_{2} \rightarrow \mathrm{FMN}+\mathrm{H}_{2} \mathrm{O}+\mathrm{R}-\mathrm{COOH}+\mathbf{h v} .
$$

A swift replacement of the substrates is needed in order to produce continuous light, so the substrates are recycled by being re-reduced by a flavin reductase, a fatty acid reductase, and a different hydrogen source, NADH:

$$
\mathrm{NADH}+\mathrm{FMN}+\mathrm{H}^{+}+\mathrm{R}-\mathrm{COOH} \rightarrow \mathrm{NAD}^{+}+\mathrm{FMNH}_{2}+\mathrm{R}-\mathrm{CHO}
$$

(Haddock et al. 2010, Meighen 1991, Shimomura et al. 1972).

The light produced by the bacteria in the bioluminescent reaction is usually a blue color, wavelength around $490 \mathrm{~nm}$, in sea water because blue light penetrates further than other wavelengths of light. In exceptionally rare occasions, a yellow wavelength around $520 \mathrm{~nm}$, in shallower or more coastal waters has been observed. The yellow color is produced by a yellow fluorescent protein and fluorescence resonance energy transfer from luciferase (Hastings 1996, Widder 2010.

Bioluminescence in these bacteria is controlled by quorum sensing. Quorum sensing is a cell-density based communication system that uses concentrations of chemical signals to convey messages about population size, surrounding bacterial populations and the environment. These messages trigger the bacteria's genetic response to external stimuli that concern survival, propagation, and virulence in certain species. Most quorum sensing communication is intraspecific, but certain signals are thought to be used for inter-specific communication (Park et al. 2006, Qin et al. 2007). 
The quorum sensing molecules were first known as autoinducers (Nealson et al. 1970, Qin et al. 2007). Each bacteria species that modulates its gene expression on the basis of celldensity has their own signaling molecule. Depending on the relatedness of the species, some of these molecules may be similar but there is a specific signal for each species. The specific type of autoinducer-1 (AI-1) used most often by Gram-negative bacteria, a group to which all bioluminescent bacteria belong, is an $\mathrm{N}$-Acyl-homoserine lactone (AHL). Another class of autoinducers found in many Gram-negative bacteria are called the autoinducer-2 (AI-2) class, which are furanosyl borate esters, and they work in conjunction with the primary autoinducer signal (McDougald et al. 2003, Shen et al. 2010). The primary autoinducer is responsible for the intra-specific communication of bacteria, and in those species that contain the AI-2 signal; it is responsible for inter-specific communication. The inter-specific communication, also known as cross-talk, is capable of modulating gene expression among which is bioluminescence (McDougald et al. 2003).

Quorum sensing induces gene expression in bacteria when the cell-density of that population reaches a certain level for that gene. At this point the autoinducers have reached a threshold concentration in the surrounding environment to trigger the desired response. Population size is implied by the concentration of autoinducers, so that way there are enough cells to produce an appropriate response, such as produce enough bioluminescence to be seen or produce enough toxin to affect the host (Qin et al. 2007). So genes controlled by quorum sensing are not directly under the influence of population size or cell-density, but on autoinducer concentration, which in nature is a function of those parameters. This is useful for experimentally manipulating gene expression in these bacteria because the desired process can be stimulated by an appropriate introduction of chemicals instead of waiting for growth. 
In the $V$. harveyi model, there are two regions which are involved in the light production reaction. The first region, lux region $\mathrm{I}$, is responsible for creating the enzymes required for the reaction. Region I includes $\operatorname{lux} A / B$ which code for the $\alpha$ and $\beta$ subunits of the luciferase and lux $C / D / E$ code for the subunits of a fatty acid reductase, which recycles the main substrate of the reaction (Martin et al. 1989). Marine bioluminescent bacterial luminescence genes are organized into luxCDABEG, and are known as the lux operon (Nijvipakul et al. 2008).

The second region of $l u x$ genes is involved in quorum sensing and the regulation of the lux operon. There are different genes associated with this region depending on the species. For example, both $A$. fischeri and $V$. harveyi have the genes $l u x S / P / Q / O$ but $A$. fischeri has the additional genes luxI/R while $V$. harveyi has the genes luxM/N for AI-1 (Jung et al. 2007, McDougald et al. 2003, Meighen 1991). The genes these two species have in common (lux $S / P / Q / O$ ) are involved with the AI-2 class of autoinducers. The primary autoinducers of both A. fischeri and $V$. harveyi are AHLs are coded for by luxI and luxM respectively. The product LuxR is an autoinducer dependent transcription factor, and when it binds to the autoinducer produced by luxI, the two form a complex that binds to the lux operon promoter and activates transcription. The product LuxN is a histidine kinase transmembrane autoinducer sensor specific for the product of $\operatorname{lux} M$. The product LuxN functions similarly to the way the AI-2 pathway activates lux operon expression.

Autoinducer-2 is produced by $\operatorname{lux} S$, and there is a two part sensor coded by the $\operatorname{lux} P / Q$ genes which transduces the AI-2 signal. The product LuxP is also a transmembrane autoinducer sensor and LuxQ is a two-component sensor/kinase. The mechanism is that the AI-2 signal binds to LuxP which then activates LuxQ, which then transduces the signal to LuxO. The $V$. harveyi lux $M / N$ and $\mathrm{AI}-2$ systems both modulate the expression of $l u x O$, which codes for the response regulatory protein. In the presence of AI's, LuxN and LuxQ autophosphorylate and transfer a 
phosphate to the phosphotransferase protein, LuxU, which in turn passes it to the luxO gene. Phosphorylated LuxO activates lux operon repressors, sRNA's, which destabilize luxR, whose product is required for the transcription of the lux operon (Henke and Bassler 2004). In the absence of AI's, the kinases act as phosphatases, and with LuxO dephosphorylated the lux operon can be expressed (Chen et al. 2002, McDougald et al. 2003). Vibrio harveyi quorum sensing is also affected by the primary autoinducer of $V$. cholerae, CAI-1, produced by cqsA and received by the sensor produced by cqsS and integrated through the luxO gene (Henke and Bassler 2004).

It has recently been discovered that there is an additional class of molecules, cyclic dipeptides, that can influence quorum sensing systems. A number of these cyclic dipeptides have been found to both inhibit and activate gene expression in some quorum sensing controlled genes in a number of Gram-negative bacteria, although at much higher concentrations than normal signals like AHLs. Some of these bacteria produce their own cyclic dipeptides. Since these molecules have been found in a wide variety of bacteria, they are being considered for an interspecific quorum sensing signal. Cyclic dipeptides are also found in fungi, and produce a number of effects in animals and plants it has been suggested that they may be involved in inter-kingdom communication (Bina and Bina. 2010, Campbell et al. 2009, Park et al. 2006).

Work on Vibrio spp. and cyclic dipeptides started with $V$. vulnificus, an opportunistic human pathogen, where Park and his team (2006) concluded that $V$. vulnificus lacked any AHL gene homolog, like luxI/M, and instead uses cyclic-phenylalanine-proline, cFP, as a quorum sensing signal. They found that $\mathrm{cFP}$ induced expression of OmpU, a quorum sensing gene involved in virulence, and cholera toxin (CT) in V. cholerae, another human pathogen which is responsible for the disease cholera. Then conflicting data came from Bina and Bina (2010) specifically about $V$. cholerae in which they showed that instead of inducing the expression of $\mathrm{CT}$, it significantly inhibited expression. They did show that expression of OmpU in $V$. cholerae 
was increased in the presence of cFP, although the increase was small or close to none at all. These differences were difficult to reconcile and were thought to arise from strain specific differences as well as subtle differences in media and methods used.

Another study published by Campbell et al. (2009), who determined that cFP inhibited quorum sensing activity through LuxR and also inhibited luminescence by reducing the number of active luciferases in A. fischeri. Although cFP was found to act on quorum sensing through LuxR, it did not compete with the primary autoinducers, the AHLs. Thus, it is still not clear whether cyclic dipeptides fit into the category of true quorum sensing molecules or not. These studies did not include $V$. harveyi. With that in mind, my work focused on $V$. harveyi, the organism from which quorum sensing (autoinduction) was discovered (Nealson et al. 1970) to determine the role of cFP on quorum sensing using electrospray mass spectrometry.

A broader impact of my study is that Vibrio cholerae is a relative of $V$. harveyi and they both share a similar quorum sensing system. The other impacts of this study may also be seen more generally, further understanding of quorum sensing and bioluminescent bacteria will enhance the ability of the scientific community to utilize bioluminescent bacteria for increased clinical and experimental applications.

Vibrio harveyi, the organism of interest in this project, is a marine bioluminescent bacterium. Like most other bioluminescent bacteria, it is Gram negative. In nature $V$. harveyi may exist planktonically, in fish intestines, or as a pathogen for some marine organisms such as shrimp (Makemson and Hermosa 1999, Mok et al. 2003).

My project had three aims related to the function of the supposed signaling molecule, cyclo(Phe-Pro), on the quorum sensing of $V$. harveyi. The first specific aim was to determine whether $V$. harveyi truly produces $\mathrm{cFP}$ or not. That aim was accomplished by attempting to 
identify what concentrations cFP is produced and how the bacterium is grown affects cFP production. Because electrospray mass spectrometry (ESMS) was used, a by-product of the first aim was to account for many of the extracellular molecules produced by $V$. harveyi. The second aim was determine the effects that $\mathrm{cFP}$ has on $V$. harveyi gene expression, metabolic profile, growth, and bioluminescence. The third specific aim was to determine what effect $\mathrm{cFP}$ has on in vitro luciferase activity of $V$. harveyi. 


\section{Materials and Methods}

For most experiments five strains of $V$. harveyi were used: MAV, BB120, BB170, BB152, and the BB886 strain. The first two strains are wild-type and the other three are signaling mutants. In order to determine whether $V$. harveyi produces cFP bacterial cultures were analyzed using simple electrospray mass spectrometry (Makemson et al.2006). Each strain was inoculated into two different media: Autoinducer Bioassay $(\mathrm{AB})$ and Minimal. Autoinducer Bioassay media consists of 10mM HEPES, $0.3 \%$ glycerol, $0.2 \%$ casamino acids, $0.02 \%$ glycerol phosphate, $1 \mathrm{uM}$ ferric chloride, and 75\% artificial saltwater (ASW). Minimal media consists of 10mM HEPES, $0.3 \%$ glycerol, $0.2 \%$ ammonium chloride, $0.02 \%$ glycerol phosphate, $1 \mathrm{uM}$ ferric chloride, $0.0001 \%$ yeast extract, and $75 \% \mathrm{ASW}$. The artificial seawater (ASW) consists of $0.5 \mathrm{M} \mathrm{NaCl}, 25$ $\mathrm{mM} \mathrm{MgSO}_{4}, 25 \mathrm{mM} \mathrm{MgCl}_{2}$, and $10 \mathrm{mM} \mathrm{KCl}$.

Cultures examined with ESMS used 3-5 mL aliquots to which one was acidified by the addition of $20 \mu \mathrm{L}$ glacial acetic acid $/ \mathrm{mL}$ medium and the other being made basic by the addition of $20 \mu \mathrm{L} 4 \mathrm{M} \mathrm{NaOH} / \mathrm{mL}$ medium. Each aliquot was then be extracted with ethyl acetate three times, combined and evaporated at $35^{\circ} \mathrm{C}$, and re-suspended in methanol. These extracts and extracts of pure media were analyzed using ESMS to determine the presence of cFP, which should have a peak at 245 mass-charge ratio (m/z) (Park et al. 2006).

To determine the effect that cFP has on $V$. harveyi gene expression, effects on metabolic profile were quantified through the use of 96 well Biolog GN plates (Biolog, Hayward, CA). Each well contains a different compound which when metabolized produces a blue color. These plates are used to distinguish between strains of marine luminous bacteria (Makemson et al. 1998). The Wild-Type strains (MAV and BB120) were streaked overnight onto agar plates of Glycerol Marine Agar (GMA: $0.5 \%$ peptone, $0.1 \%$ yeast extract, $0.02 \%$ glycerol phosphate, $0.3 \%$ glycerol, and $75 \%$ ASW) for the control suspensions. Another set was streaked onto plates 
containing $5 \mu \mathrm{M} \mathrm{cFP}$ for the experimental suspensions. Cells from each plate were then suspended into $25 \mathrm{~mL}$ of $0.75 \mathrm{X}$ artificial seawater (or $0.75 \mathrm{X}$ artificial seawater and $5 \mu \mathrm{M} \mathrm{cFP}$ ), and adjusted to $\mathrm{OD}_{660 \mathrm{~nm}}$ of $0.25 \pm 0.1$ using a Spectronic 20. These suspensions were used to inoculate the Biolog GN plates.

To determine the effect of cFP on bioluminescence, split cultures were used. Each strain was inoculated into $\mathrm{AB}$ media and grown until varying stages of exponential growth (beginning, middle, and end) and then split and grown with different concentrations of cFP. Growth, monitored with $\mathrm{OD}_{660 \mathrm{~nm}}$, and light output (Mitchell and Hastings 1971) was measured with a luminometer.

In order to determine the effect of cFP on luciferase activity, the standard luciferase assay was used with lysed (toluene treated) cells. The standard luciferase assay uses hydrogen reduced $\mathrm{FMNH}_{2}$ to initiate the reaction after mixing luciferase preparations with decanal (fatty aldehyde) in .05M phosphate buffer, $\mathrm{pH} 7.0$ containing $0.2 \%$ bovine serum albumin (Hastings et al. 1978). 


\section{Results}

\section{Aim 1: Electrospray Mass Spectrometry Detection of $V$. harveyi Extracellular Molecules}

Mass spectrometry has been used to identify homoserine lactones (HSL), the major class of quorum sensing molecules used by Gram negative bacteria, from cell-free culture extracts. Using that ability Vibrio harveyi was analyzed to determine if it produces the potential quorum sensing signaling molecule cyclic-phenylalanine-proline (cFP). There were no significant peaks in any of the mass spectrometric analyses (extracts of acidic and alkalinized media after growth of each $V$. harveyi strain: MAV, BB120,BB170, BB152, and BB886) at m/z 245, where cFP should be found, other than the molecules that present at that $\mathrm{m} / \mathrm{z}$ from the uninoculated media (Fig. 1). The lack of increase in peak height in the experimental extracts compared to the control extract suggests that $V$. harveyi does not produce cFP naturally (Fig. 2). To be sure, additional analyses could be made on extracts of both inoculated and uninoculated media with a tandem mass spectrometer to be certain that the constituents at the $245 \mathrm{~m} / \mathrm{z}$ are the same in both situations.

Beyond determining that none of the five $V$. harveyi strains examined produced $\mathrm{cFP}$, the mass spectrometric analyses revealed a large number of additional extractable molecules produced by $V$. harveyi. There were 94 peaks found amongst all of the $V$. harveyi strains representing these molecules, after all of the peaks common to both the culture media and uninoculated media and the adducts were subtracted. A number of these molecules are shared between each strain with the remaining molecules being unique to that particular strain.

Some of the molecules fit the profile of being HSL's. These HSL's will only be extracted in the acidified media and be absent from extracts made from alkaline media due to the opening of the lactone ring in alkaline conditions which makes the HSL hydrophilic and not 
A

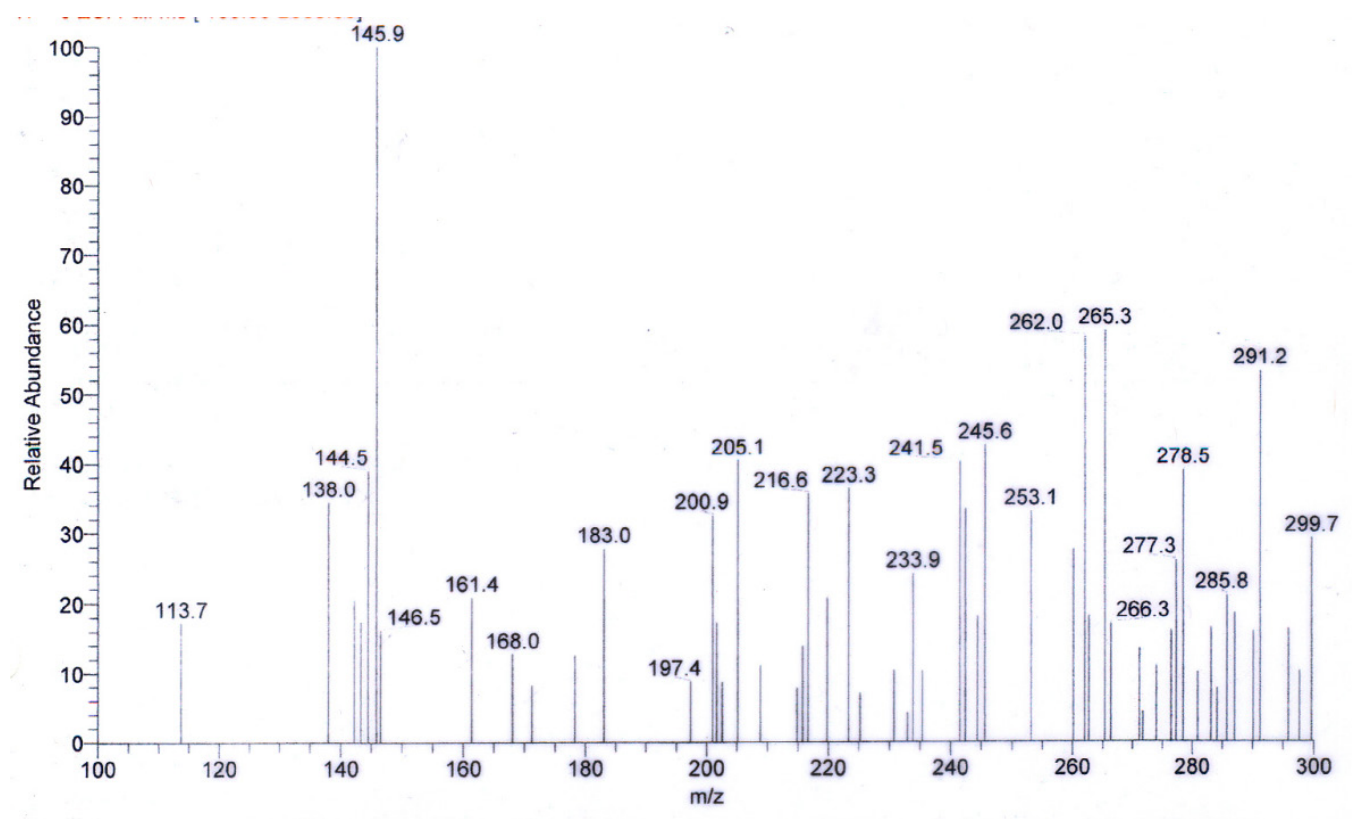

B

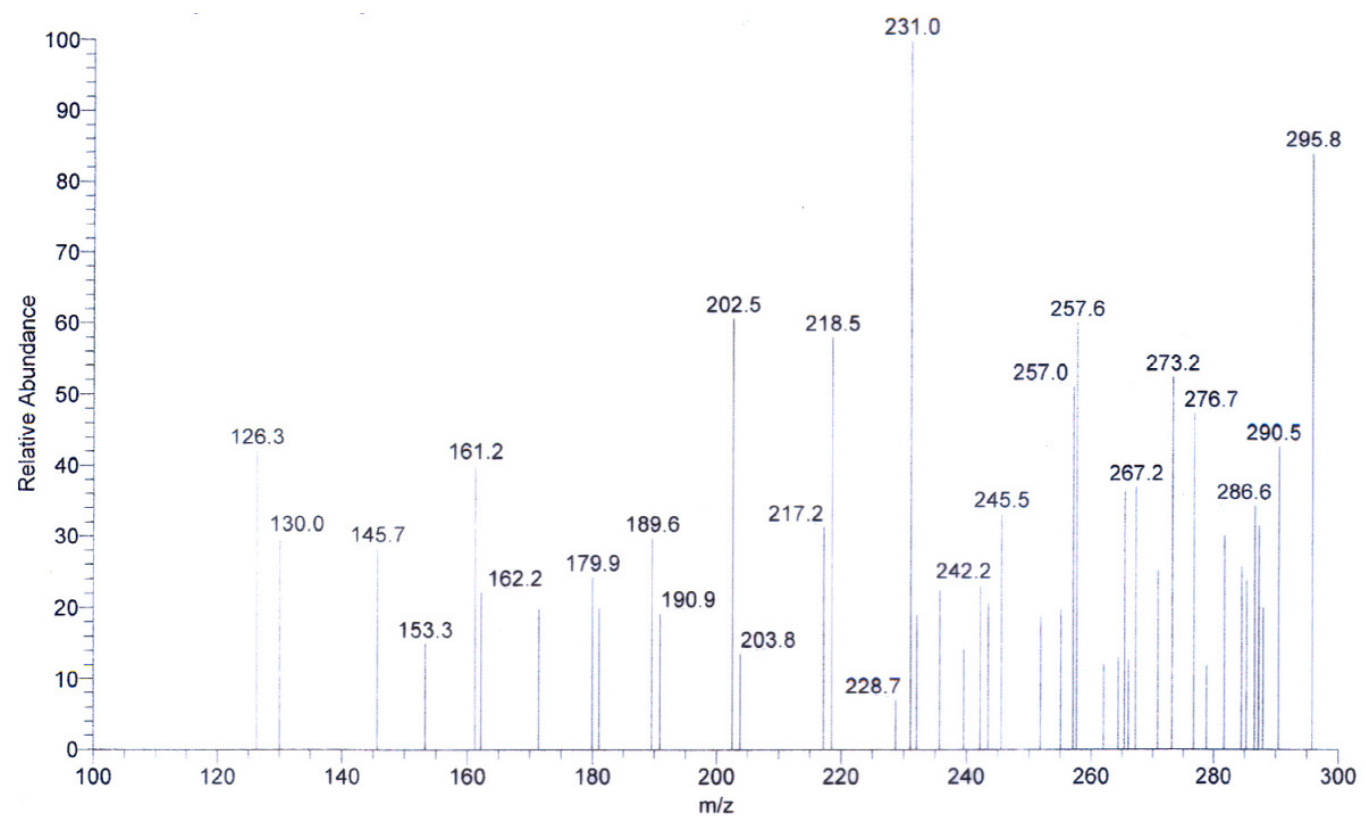

Figure 1 Mass Spectra of Uninoculated AB Media. A. Mass spectrum of extract of acidified AB media, with a peak at $245 \mathrm{~m} / \mathrm{z}$ which corresponds to cFP. B. Mass spectrum of extract of alkalinized AB media, with a peak at $245 \mathrm{~m} / \mathrm{z}$ which corresponds to cFP. 
A

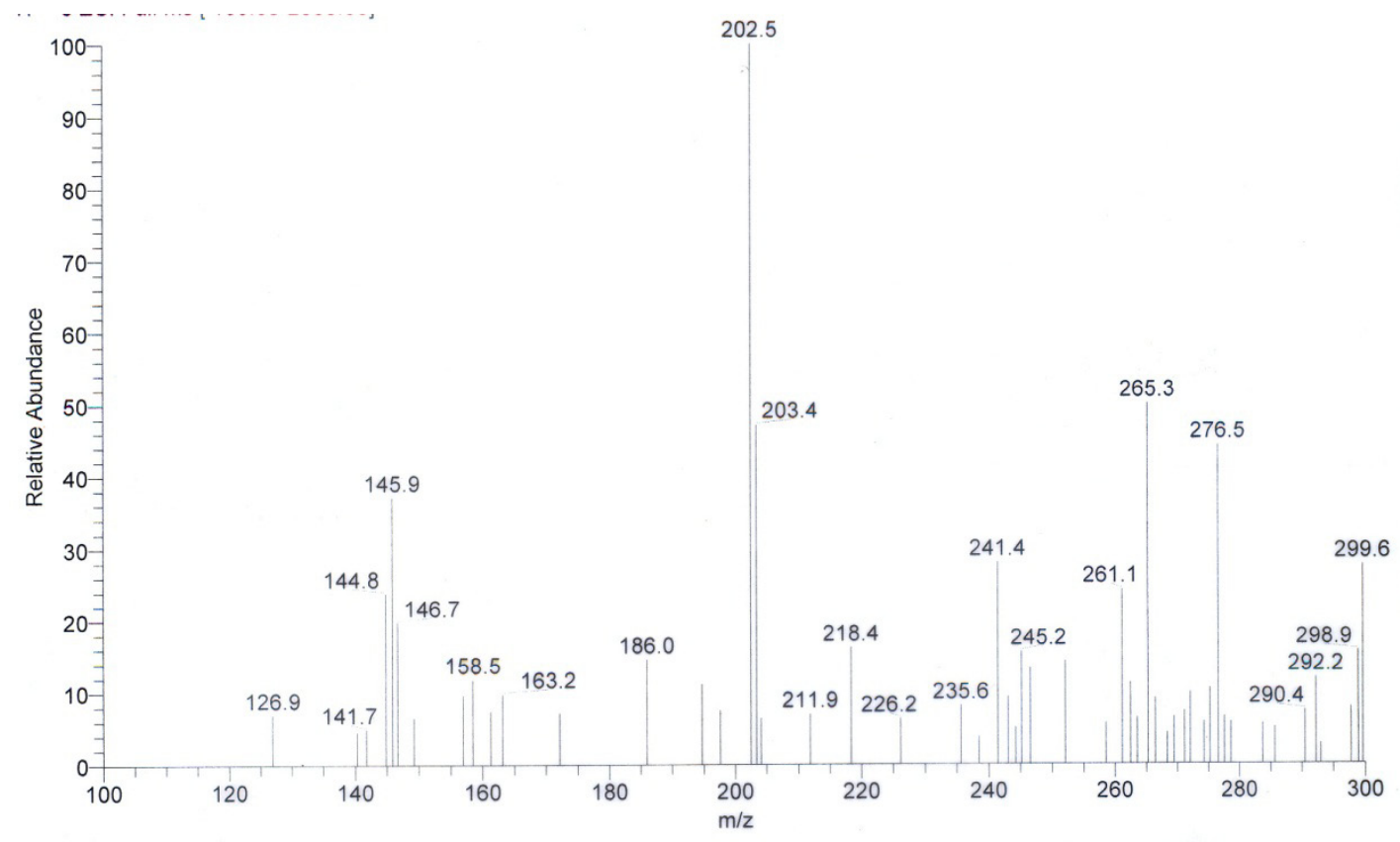

B

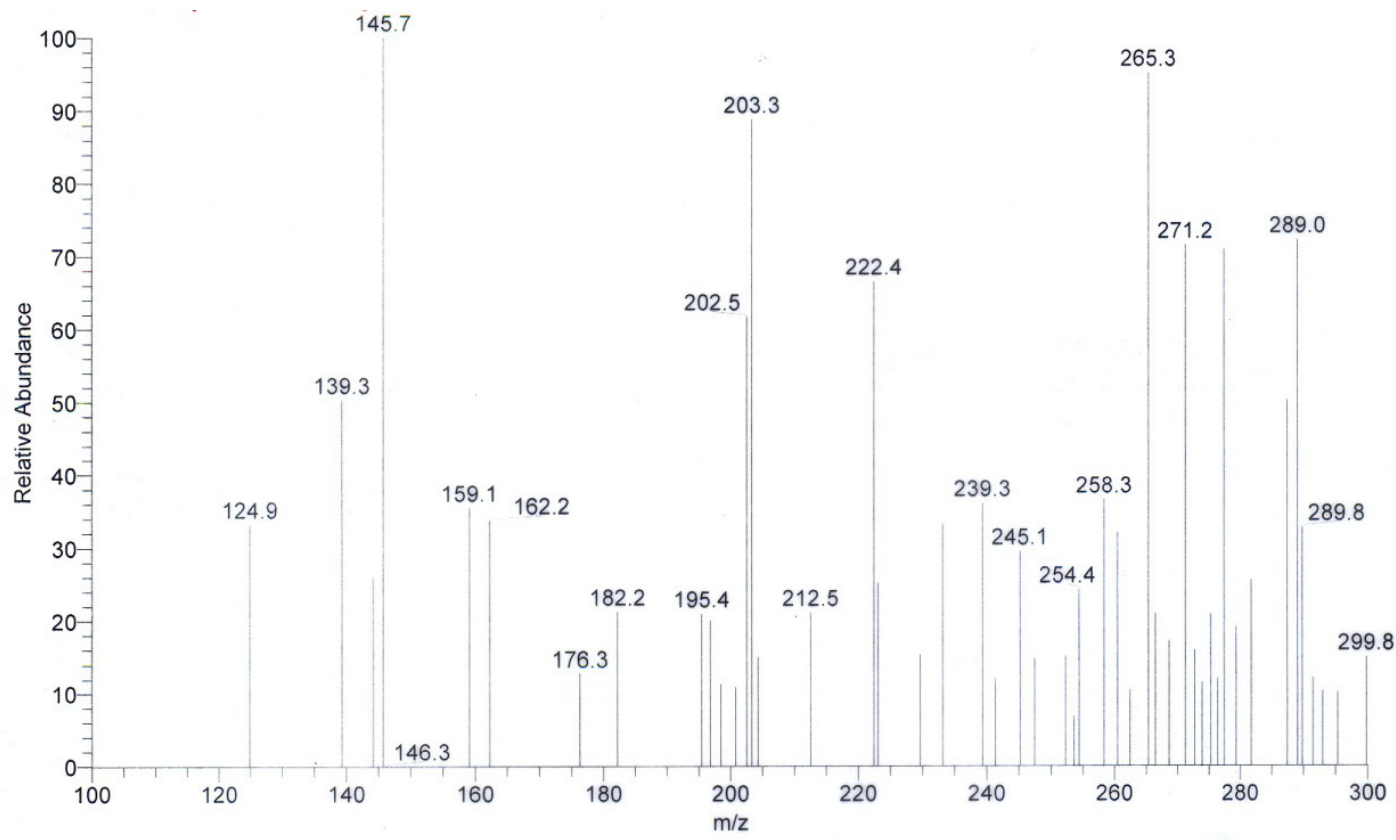

Figure 2 Mass Spectra of MAV in AB media. A. Mass spectrum of extract of acidified cell-free culture of $V$. harveyi MAV, with a peak at $\mathrm{m} / \mathrm{z} 186$ ( $N$-(3-hydroxybutanoyl) homoserine lactone). B. Mass spectrum of extract of alkalinized cell-free culture of $V$. harveyi MAV, without a peak at $\mathrm{m} / \mathrm{z} 186$. 
extract into ethyl acetate. This trait allows potential HSL's to be identified by comparing the mass spectra of the acidic culture extract and the basic culture extract; where peaks that drop out from the former to the latter are potential HSL's. An example of this can be seen in $V$. harveyi MAV, where in the extract of acidic media there is a peak at $\mathrm{m} / \mathrm{z} 186$ (Fig.2A), corresponding to the signal $\mathrm{N}$-(3-hydroxybutanoyl) homoserine lactone, and that peak is absent in the extract of basic media (Fig. 2B).

All potentials signals are present in Appendix 1, where each strain has a list of detected molecules in the extracts from both acidified and alkalinized media and potential HSL's will only be listed in the acidic extract column. Table 1 is an abbreviated list of molecules produced by $V$. harveyi. It shows the likely $\mathrm{m} / \mathrm{z}$ 's of the known signals as well as some representative molecules for each strain and the molecules common to many of the strains. Each strain of $V$. harveyi (MAV, BB120, BB170, and BB886) examined except BB152 had similar peaks near m/z 186. This $\mathrm{m} / \mathrm{z}$ corresponds to $\mathrm{N}$-(3-hydroxybutanoyl) homoserine lactone, also referred to as HA1 because it is the primary signal of $V$. harveyi. Strain BB152 lacks this peak, as expected, because it is a signaling mutant in $\operatorname{lux} M$, the gene responsible for producing HA1.

The m/z's for the remaining known signaling molecules of $V$. harveyi were less straight forward, and varied about $+/-1 \mathrm{~m} / \mathrm{z}$ from strain to strain but were limited to the expected region. This is due to the daily, slight fluctuations in ESMS calibration. Each strain had peaks from $\mathrm{m} / \mathrm{z}$ 193-195, which corresponds to the $\mathrm{m} / \mathrm{z}$ of the un-boronated precursor of the signal AI2 (3Amethyl-5,6-dihydro-furo(2,3-D)(1,3,2)dioxaborole-2,2,6,6A-tetraol), the inter-species signal common to many Gram negative bacteria. Each strain also had peaks from $\mathrm{m} / \mathrm{z} 212-215$, which corresponds to the $\mathrm{m} / \mathrm{z}$ for the main autoinducer of $V$. cholerae CA1 (S-3-hydroxytridecan-4one). 
The rest of the molecules present in the mass spectra analyzed are produced by $V$. harveyi and are currently unidentified. These molecules can be further investigated with tandem mass spectrometry (currently not available at FIU) in order to determine structure and possibility of being a quorum or other sensing signal.

\begin{tabular}{|c|c|c|c|c|c|c|c|c|c|c|c|}
\hline $\mathrm{m} / \mathrm{z}$ & & $\mathrm{MAV} / \mathrm{H}$ & $\mathrm{MAV} / \mathrm{OH}$ & $120 / \mathrm{H}$ & $120 / \mathrm{OH}$ & $170 / \mathrm{H}$ & $170 / \mathrm{OH}$ & $152 / H$ & $152 / \mathrm{OH}$ & $886 / \mathrm{H}$ & $886 / \mathrm{OH}$ \\
\hline 144 & & & & & & & $x$ & & $x$ & & $x$ \\
\hline 146 & & & $x$ & & & & $x$ & & $x$ & & $x$ \\
\hline 172 & & $\mathrm{x}$ & & $x$ & & $\mathrm{x}$ & & $x$ & & & \\
\hline 186 & Al-1 & $x$ & & $x$ & & $x$ & & & & $x$ & \\
\hline 193 & $\mathrm{Al}-2 \mathrm{P}$ & & & & & $x$ & & & & $x$ & \\
\hline 194 & $\mathrm{Al}-2 \mathrm{P}$ & $x$ & & & & & & & & & \\
\hline 195 & $\mathrm{Al}-2 \mathrm{P}$ & & $\mathrm{x}$ & $x$ & & & & & & & $\mathrm{x}$ \\
\hline 202 & & $x$ & & $x$ & & $x$ & & & & & \\
\hline 203 & & & $x$ & & & & & $\mathrm{x}$ & & $\mathrm{x}$ & \\
\hline 212 & CA-1 & $x$ & & & & & & & & & \\
\hline 213 & CA-1 & & & & & & & $x$ & & & \\
\hline 214 & CA-1 & & & $x$ & & & & & & & \\
\hline 215 & CA-1 & & & & & $x$ & & & & & \\
\hline 237 & & $x$ & & & & $x$ & & $x$ & & & \\
\hline 251 & & & & & $x$ & & $x$ & & & $x$ & \\
\hline 256 & & & & & & $x$ & & $\mathrm{x}$ & & $x$ & \\
\hline
\end{tabular}

Table 1 List of Major Extracellular Molecules Detected by Mass Spectrometry. An abbreviated table showing the $\mathrm{m} / \mathrm{z}$ 's and potential identities of molecules produced by various $V$. harveyi strains (MAV, BB120, BB170, BB152, BB886) and found in both acidified and alkalinized cell-free culture extracts and analyzed by electrospray mass spectrometry. 


\section{Aim 2: Gene Expression, Growth, and Bioluminescence}

The two Wild-Type strains (MAV, BB120) were analyzed with the Biolog GN plates to determine if cFP had any effect on the $V$. harveyi metabolic profile. There were three different conditions tested for these strains: grown on GMA and suspended in .75x ASW, grown on GMA and suspended in $.75 \mathrm{x}$ ASW with $5 \mu \mathrm{M} \mathrm{cFP}$, and grown on GMA with $5 \mu \mathrm{M} \mathrm{cFP}$ and suspended in $.75 \mathrm{x}$ ASW with $5 \mu \mathrm{M}$ cFP. While the metabolic profiles of MAV and BB120 differed slightly, the three conditions of each strain shared the same metabolic profile (Table 2). Since being grown under conditions exposing the $V$. harveyi to cFP had no effect on their profiles, it appears cFP has no effect on the metabolic profile of $V$. harveyi. 


\begin{tabular}{|c|c|c|c|c|c|c|c|c|c|c|c|c|}
\hline & $1-$ & $2-$ & 3- & 4- & 5- & 6- & 7- & 8- & 9- & $10-$ & $11-$ & $12-$ \\
\hline A & & $\begin{array}{l}\alpha- \\
\text { cyclodextri } \\
n\end{array}$ & dextrin & glycogen & tween 40 & tween 80 & $\begin{array}{l}\mathrm{N} \text {-acetyl- } \\
\mathrm{D} \text { - } \\
\text { galactos } \\
\text { amine }\end{array}$ & $\begin{array}{l}\mathrm{N} \text {-acetyl- } \\
\mathrm{D} \text {-glucos } \\
\text { amine }\end{array}$ & & & & cellobiose \\
\hline B & & D-fructose & & $\begin{array}{l}\text { D- } \\
\text { galactose }\end{array}$ & & $\begin{array}{l}\alpha-D- \\
\text { glucose }\end{array}$ & & & & maltose & $\begin{array}{l}\text { D- } \\
\text { mannitol }\end{array}$ & $\begin{array}{l}\text { D- } \\
\text { mannose }\end{array}$ \\
\hline C & & & psicose & & & & sucrose & $\begin{array}{l}\text { D- } \\
\text { trehalose }\end{array}$ & turanose & & $\begin{array}{l}\text { methyl } \\
\text { pyruvtate }\end{array}$ & $\begin{array}{l}\text { mono- } \\
\text { methyl } \\
\text { succinate }\end{array}$ \\
\hline D & $\begin{array}{l}\text { acetic } \\
\text { acid }\end{array}$ & & citric acid & & & & $\begin{array}{l}\text { D- } \\
\text { gluconic } \\
\text { acid }\end{array}$ & & $\begin{array}{l}\text { D- } \\
\text { glucuroni } \\
\text { c acid }\end{array}$ & & & \\
\hline E & & & & $\begin{array}{l}\alpha \text {-keto } \\
\text { glutaric } \\
\text { acid }\end{array}$ & & $\begin{array}{l}\text { D, L- lactic } \\
\text { acid }\end{array}$ & & $\begin{array}{l}\text { propionic } \\
\text { acid }\end{array}$ & & & & $\begin{array}{l}\text { succinic } \\
\text { acid }\end{array}$ \\
\hline $\mathrm{F}$ & $\begin{array}{l}\text { bromo } \\
\text { succinic } \\
\text { acid }\end{array}$ & $\begin{array}{l}\text { succinamic } \\
\text { acid }\end{array}$ & $\begin{array}{l}\text { glucuron } \\
\text { amide }\end{array}$ & & $\begin{array}{l}\text { D- } \\
\text { alanine }\end{array}$ & L-alanine & $\begin{array}{l}\text { L-alanyl- } \\
\text { glycine }\end{array}$ & $\begin{array}{l}\text { L- } \\
\text { aspargin } \\
\text { e }\end{array}$ & $\begin{array}{l}\text { L-aspartic } \\
\text { acid }\end{array}$ & $\begin{array}{l}\text { L-glutamic } \\
\text { acid }\end{array}$ & $\begin{array}{l}\text { glycyl-L- } \\
\text { aspartic } \\
\text { acid }\end{array}$ & $\begin{array}{l}\text { glycyl-L- } \\
\text { glutamic } \\
\text { acid }\end{array}$ \\
\hline G & & & & $\begin{array}{l}\text { L- } \\
\text { ornithine }\end{array}$ & & L-proline & & D-serine & L-serine & $\begin{array}{l}\text { L- } \\
\text { threonine }\end{array}$ & $\begin{array}{l}\mathrm{D}, \mathrm{L}- \\
\text { camitine }\end{array}$ & \\
\hline $\mathrm{H}$ & & inosine & uridine & thymidine & & & $\begin{array}{l}\text { 2-amino } \\
\text { ethanol }\end{array}$ & & glycerol & $\begin{array}{l}\mathrm{D}, \mathrm{L}-\alpha- \\
\text { glycerol } \\
\text { phosphate }\end{array}$ & $\begin{array}{l}\text { glucose-1- } \\
\text { phosphate }\end{array}$ & $\begin{array}{l}\text { glucose-6- } \\
\text { phosphate }\end{array}$ \\
\hline
\end{tabular}

\begin{tabular}{|c|c|c|c|c|c|c|c|c|c|c|c|c|}
\hline & $1-$ & $2-$ & 3- & 4- & 5- & 6- & 7- & 8- & 9- & $10-$ & 11- & $12-$ \\
\hline A & & & dextrin & glycogen & tween 40 & tween 80 & & $\begin{array}{l}\mathrm{N} \text {-acetyl- } \\
\mathrm{D} \text {-glucos } \\
\text { amine }\end{array}$ & & & & cellobiose \\
\hline B & & $\begin{array}{l}\text { D- } \\
\text { fructose }\end{array}$ & & D-galactose & & $\begin{array}{l}\alpha \text {-D- } \\
\text { glucose }\end{array}$ & & & & maltose & $\begin{array}{l}\text { D- } \\
\text { mannitol }\end{array}$ & $\begin{array}{l}\text { D- } \\
\text { mannose }\end{array}$ \\
\hline C & $\begin{array}{l}\text { D- } \\
\text { melibiose }\end{array}$ & $\begin{array}{l}\beta \text {-methyl } \\
\text { glucoside }\end{array}$ & psicose & & & & & $\begin{array}{l}\text { D- } \\
\text { trehalose }\end{array}$ & turanose & & $\begin{array}{l}\text { methyl } \\
\text { pyruvtate }\end{array}$ & $\begin{array}{l}\text { mono- } \\
\text { methyl } \\
\text { succinate }\end{array}$ \\
\hline D & $\begin{array}{l}\text { acetic } \\
\text { acid }\end{array}$ & $\begin{array}{l}\text { cis- } \\
\text { aconitic } \\
\text { acid }\end{array}$ & citric acid & & & & $\begin{array}{l}\text { D- } \\
\text { gluconic } \\
\text { acid }\end{array}$ & & & & & \\
\hline $\mathrm{E}$ & & & & $\begin{array}{l}\alpha \text {-keto } \\
\text { glutaric } \\
\text { acid }\end{array}$ & & & & $\begin{array}{l}\text { propionic } \\
\text { acid }\end{array}$ & & & & $\begin{array}{l}\text { succinic } \\
\text { acid }\end{array}$ \\
\hline $\mathrm{F}$ & $\begin{array}{l}\text { bromo } \\
\text { succinic } \\
\text { acid }\end{array}$ & & & alaninamide & & L-alanine & $\begin{array}{l}\text { L-alanyl- } \\
\text { glycine }\end{array}$ & $\begin{array}{l}\text { L- } \\
\text { aspargine }\end{array}$ & $\begin{array}{l}\text { L-aspartic } \\
\text { acid }\end{array}$ & $\begin{array}{l}\text { L-glutamic } \\
\text { acid }\end{array}$ & $\begin{array}{l}\text { glycyl-L- } \\
\text { aspartic } \\
\text { acid }\end{array}$ & $\begin{array}{l}\text { glycyl-L- } \\
\text { glutamic } \\
\text { acid }\end{array}$ \\
\hline G & & & & L-ornithine & & L-proline & & D-serine & L-serine & $\begin{array}{l}\text { L- } \\
\text { threonine }\end{array}$ & $\begin{array}{l}\mathrm{D}, \mathrm{L}- \\
\text { camitine }\end{array}$ & \\
\hline $\mathrm{H}$ & & inosine & uridine & thymidine & & & $\begin{array}{l}\text { 2-amino } \\
\text { ethanol }\end{array}$ & $\begin{array}{l}2,3- \\
\text { butanediol }\end{array}$ & glycerol & $\begin{array}{l}\mathrm{D}, \mathrm{L}-\alpha- \\
\text { glycerol } \\
\text { phosphate }\end{array}$ & & \\
\hline
\end{tabular}

Table 2. Biolog GN Metabolic Profiles. The metabolic profiles with oxidized substrates shown (Top: MAV, Bottom: BB120). Each condition of cFP for both strains was identical to the control. 
To determine the effect cFP had on $V$. harveyi growth and bioluminescence, cultures were grown until the beginning of autoinduction and were then split and exposed to varying concentrations of cFP. Two schemes of cFP concentrations were used: $1 \mathrm{mM}, 500 \mu \mathrm{M}, 50 \mu \mathrm{M}$, and, $5 \mu \mathrm{M}$, and $50 \mu \mathrm{M}, 5 \mu \mathrm{M}, 2.5 \mu \mathrm{M}$, and, $1 \mu \mathrm{M}$. The higher concentration scheme was used first because much of the prior work done with cFP on Vibrio spp. used concentrations near $1 \mathrm{mM}$. Upon noticing a difference in the bioluminescence changes at the low concentrations of the current scheme $(50 \mu \mathrm{M})$, the scheme was changed in order to determine the effects of low concentrations of $\mathrm{cFP}$, which were closer in magnitude to those of known signaling molecules.

None of the $V$. harveyi strains examined (MAV, BB120, BB170, BB152, BB886) seemed to have their growth significantly affected by exposure to cFP, regardless of concentration (Fig. 3). If there was any effect at all on growth, there would be a slight inhibition towards the higher end of cFP concentrations, and each strain experienced similar results.

In the same experiments bioluminescence was also observed. cFP has a varied effect on the bioluminescence of $V$. harveyi depending upon both strain and concentration. All strains had a similar pattern, the only variance being at what concentration the greatest effect was seen, which was always close between all the strains. In the higher cFP concentration experiments, the higher the concentration caused a small decrease in light production in all strains (Fig. 4A). At low concentration, from 1-5 $\mu \mathrm{M}$ cFP slightly induced bioluminescence towards the beginning of autoinduction, and then as time went on dropped beneath the levels of the control (Fig. 4B). Figures 5 - 8 illustrate the similarity between the rest of strains used (MAV, BB170, BB152, and BB886). The experiments using Minimal Media yielded similar results to those using AB Media, with slower growth and lower maximum light produced. An example of these Minimal Media experiments can be seen in Fig. 9. 
A

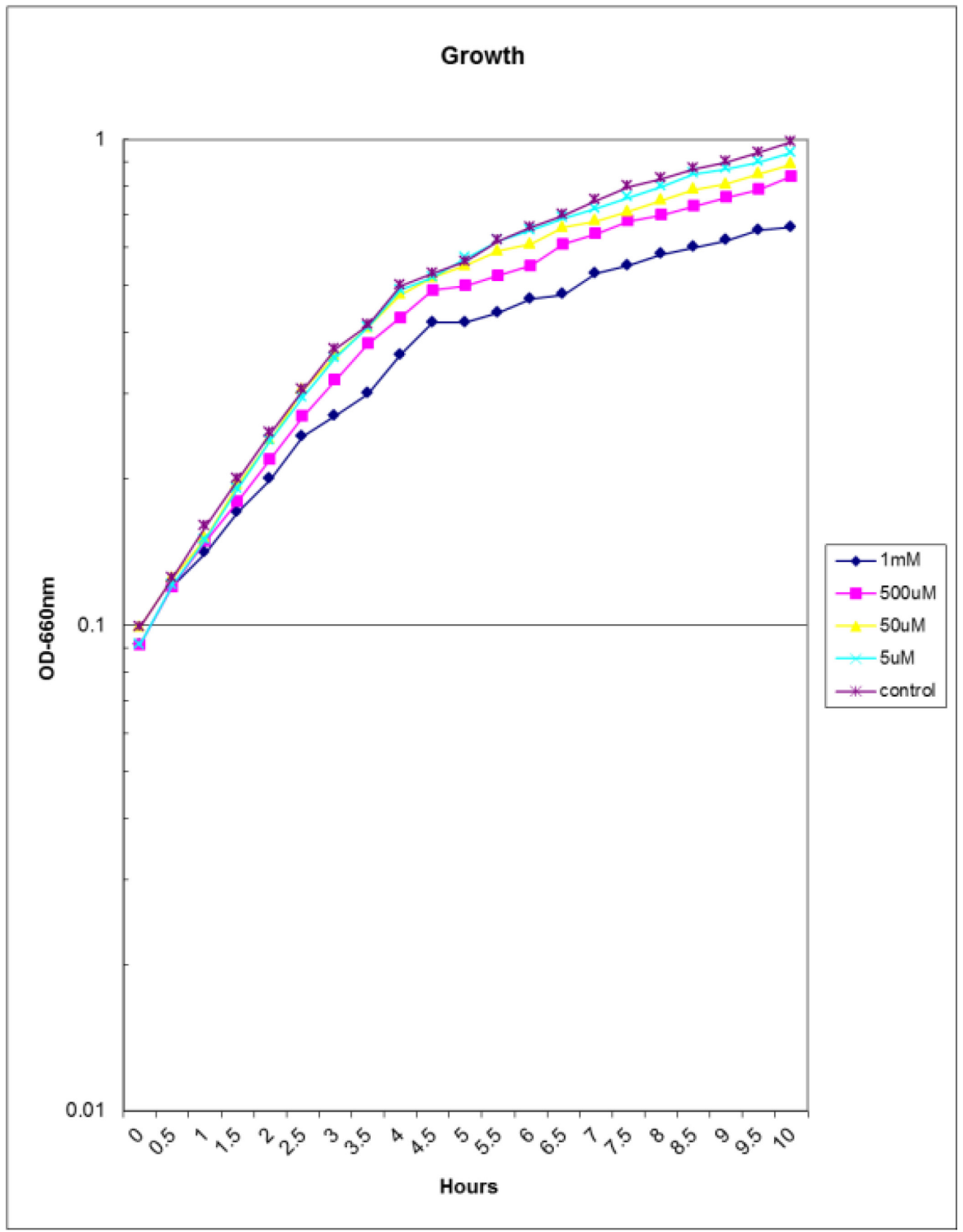

Figure 3. A. Growth curve of $V$. harveyi BB120 exposed to $1 \mathrm{mM}, 500 \mu \mathrm{M}, 50 \mu \mathrm{M}$, and $5 \mu \mathrm{M}$ cFP. Decreased growth rate is observed with higher concentration. 
B

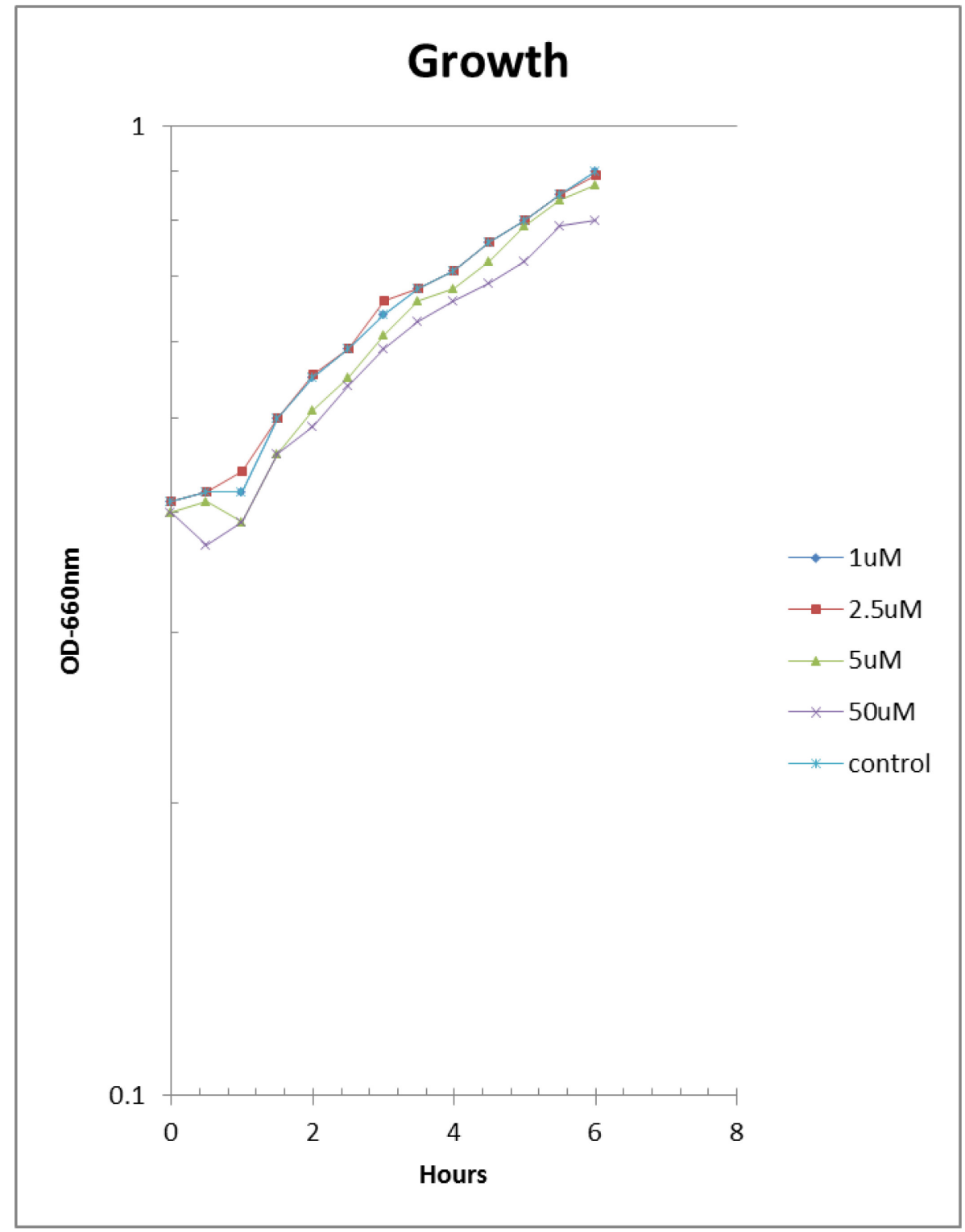

Figure 3. B. Growth curve of $V$. harveyi BB120 exposed to $50 \mu \mathrm{M}, 5 \mu \mathrm{M}, 2.5 \mu \mathrm{M}$, and $1 \mu \mathrm{M}$ cFP. Decreased growth rate is observed with higher concentration. 
A

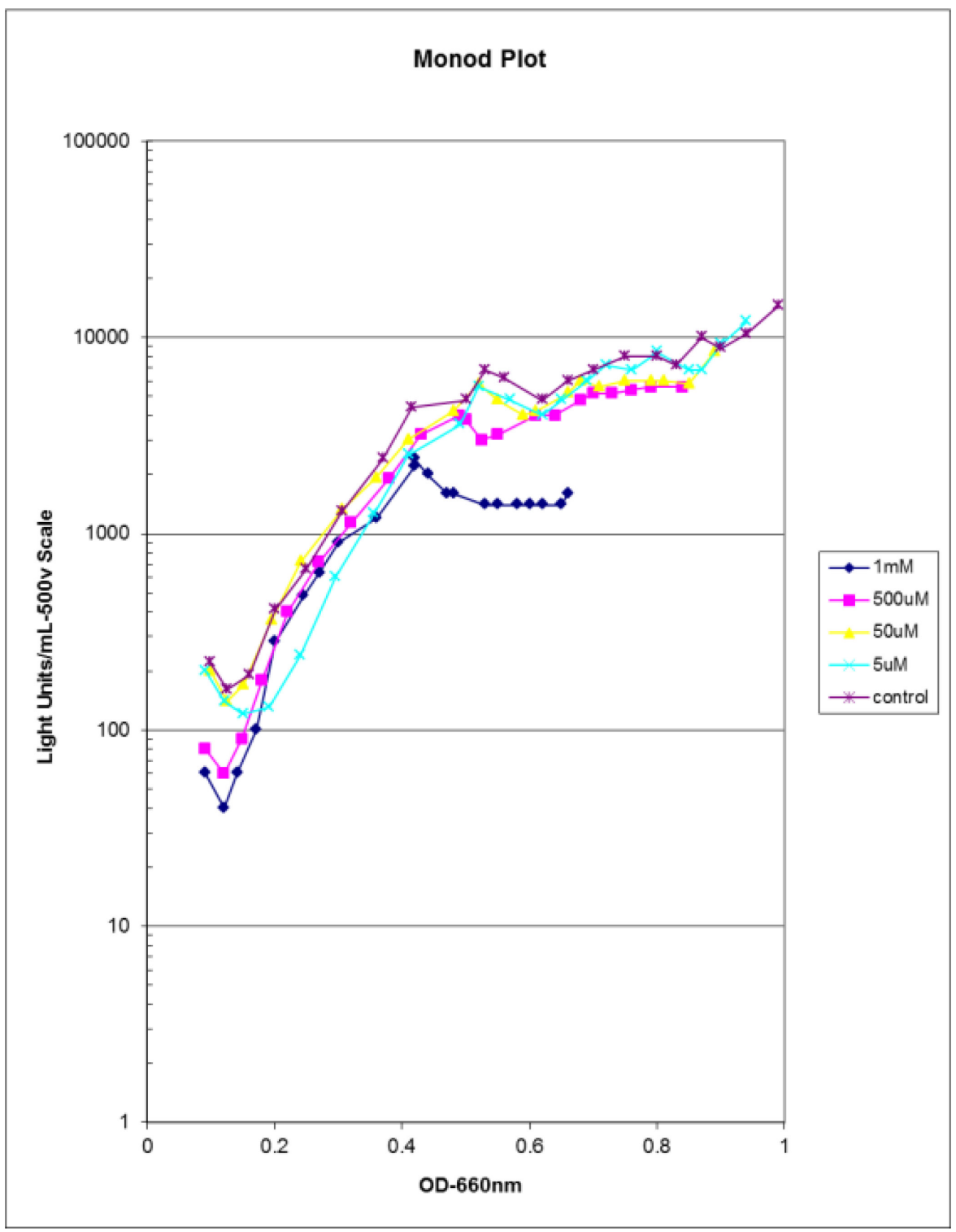

Figure 4. A. Monod Plot of $V$. harveyi BB120 exposed to $1 \mathrm{mM}, 500 \mu \mathrm{M}, 50 \mu \mathrm{M}$, and $5 \mu \mathrm{M}$ cFP. Decreased bioluminescence is observed with higher concentration. 
B

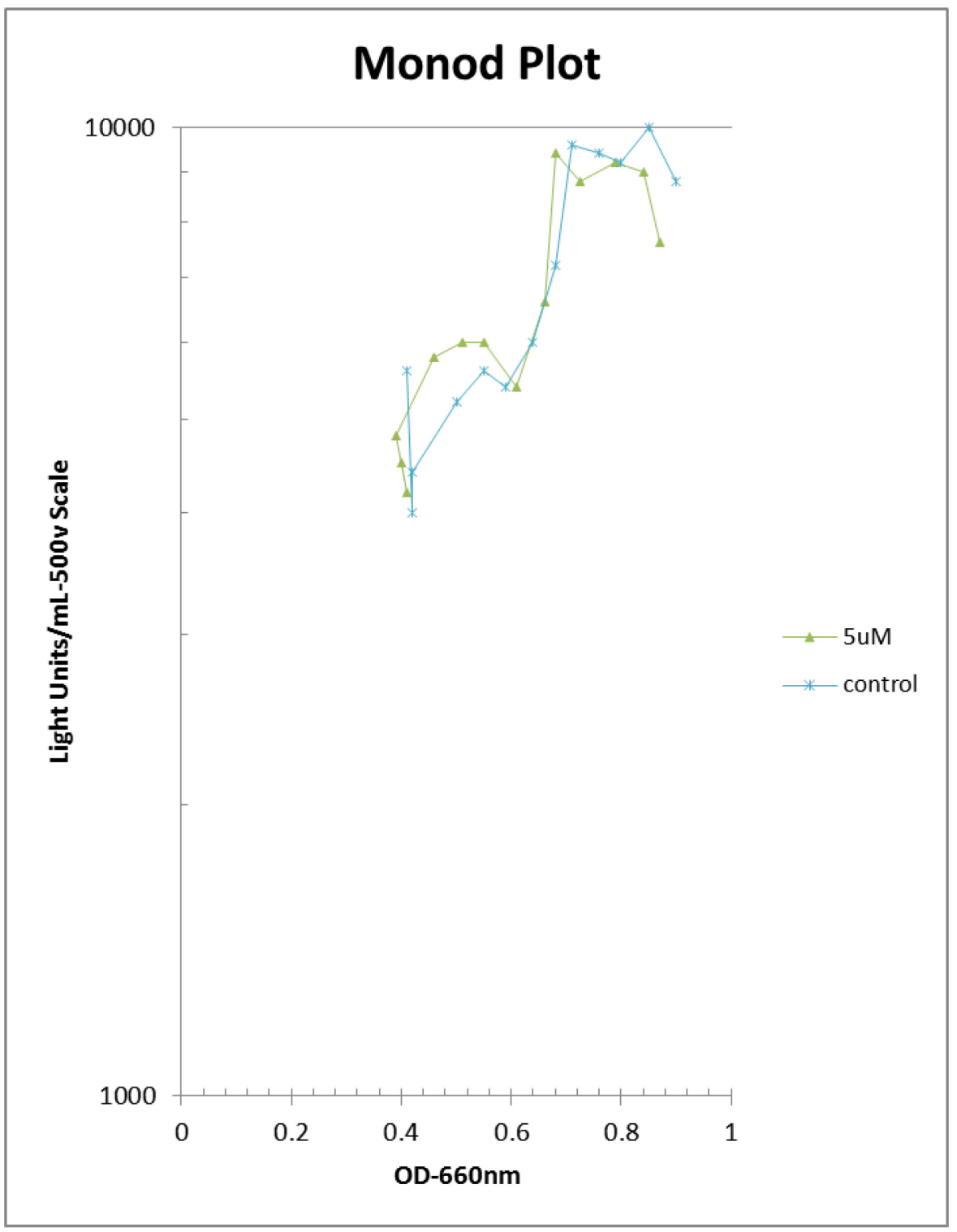

Figure 4. B. Monod Plot of $V$. harveyi BB120 exposed to $50 \mu \mathrm{M}, 5 \mu \mathrm{M}, 2.5 \mu \mathrm{M}$, and $1 \mu \mathrm{M}$ cFP (Only control and $5 \mu \mathrm{M}$ are shown). Increased levels of bioluminescence are observed in 2.5-5 $\mu \mathrm{M}$ before dropping to sub-control levels. 


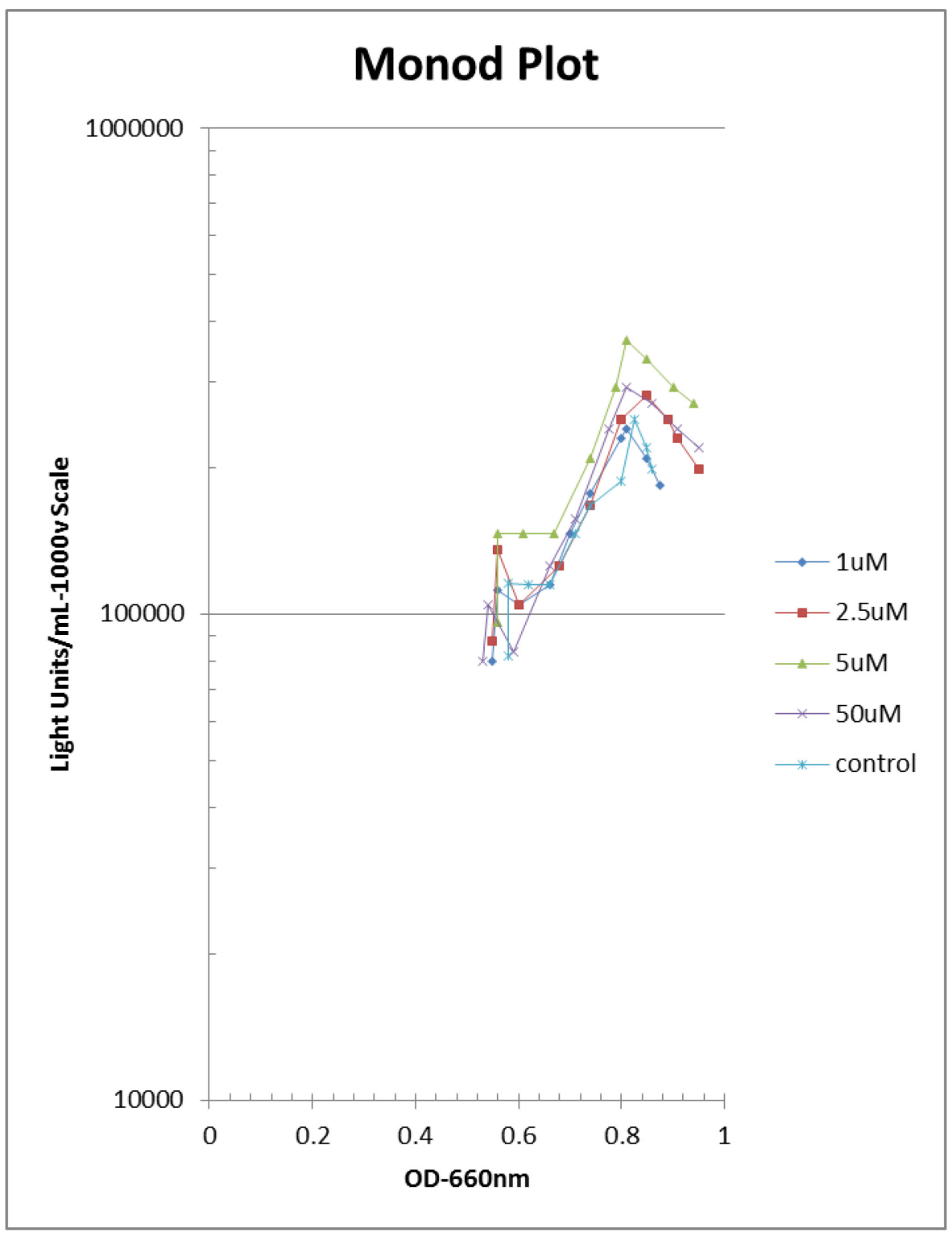

Figure 5. Monod Plot of $V$. harveyi MAV exposed to $50 \mu \mathrm{M}, 5 \mu \mathrm{M}, 2.5 \mu \mathrm{M}$, and $1 \mu \mathrm{M}$ cFP. Increased levels of bioluminescence are observed in 1-5 $\mu \mathrm{M}$. 


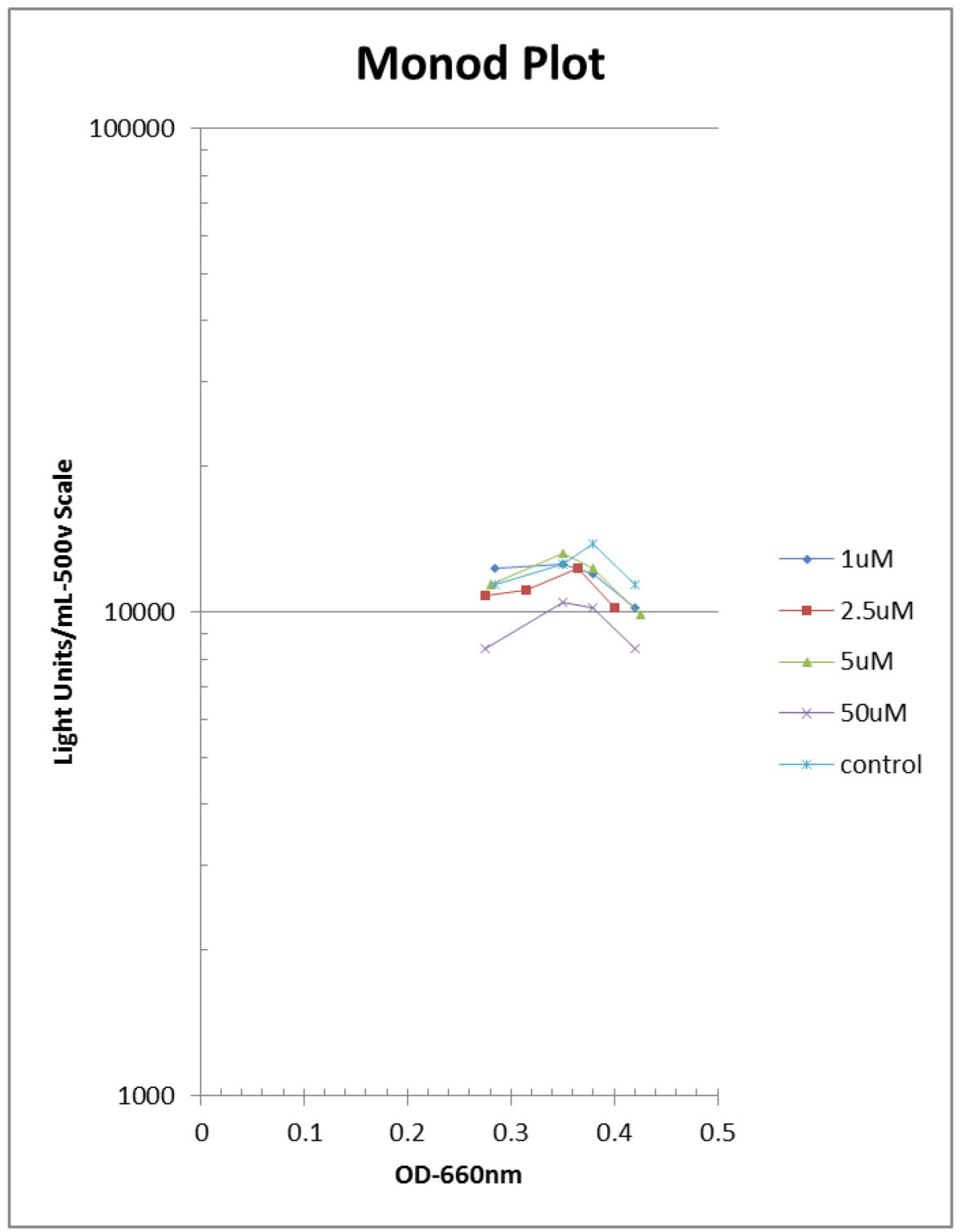

Figure 6. Monod Plot of $V$. harveyi BB170 exposed to $50 \mu \mathrm{M}, 5 \mu \mathrm{M}, 2.5 \mu \mathrm{M}$, and $1 \mu \mathrm{M}$ cFP. Increased levels of bioluminescence are observed in $1-2.5 \mu \mathrm{M}$ before dropping to sub-control levels 


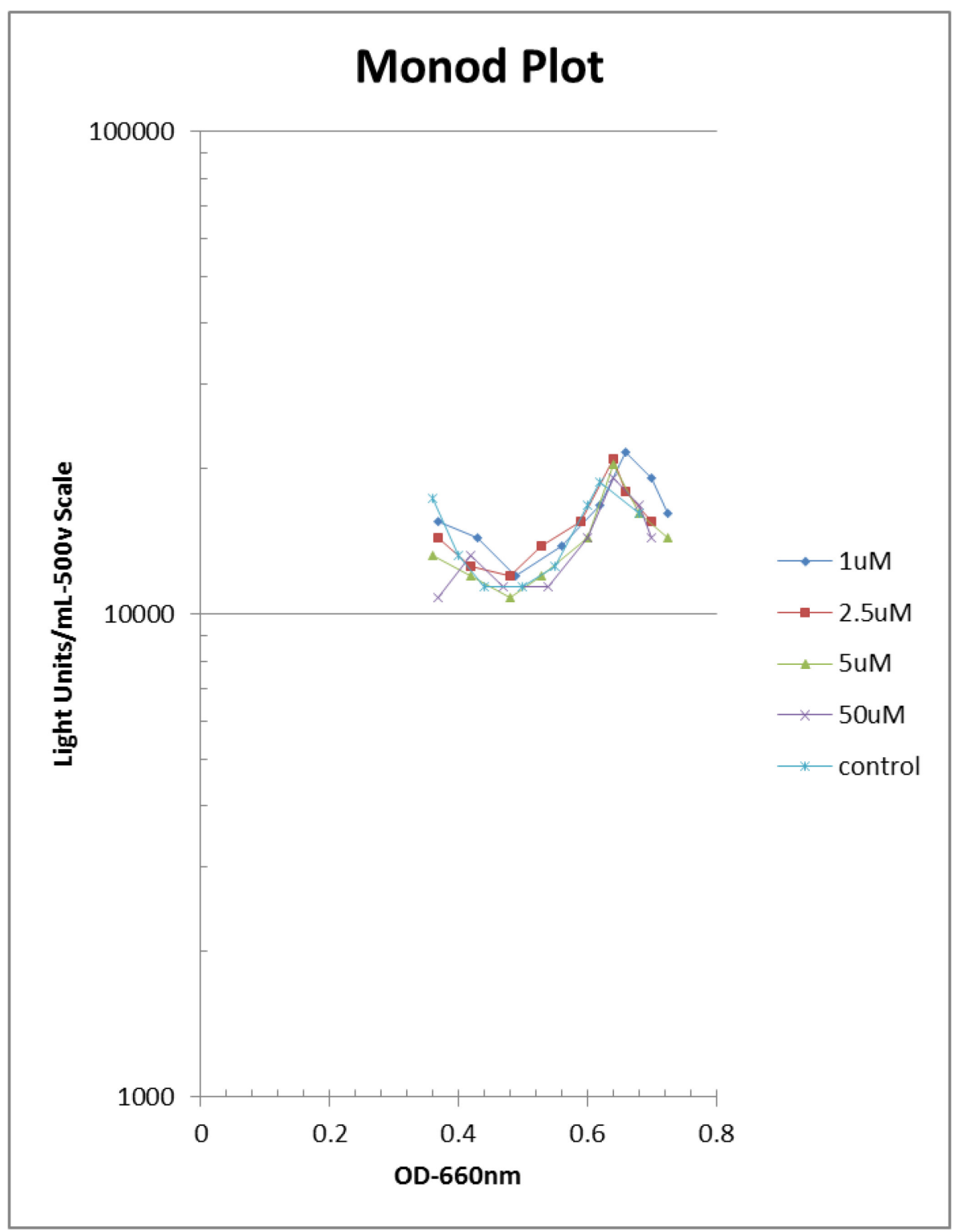

Figure 7. Monod Plot of $V$. harveyi BB152 exposed to $50 \mu \mathrm{M}, 5 \mu \mathrm{M}, 2.5 \mu \mathrm{M}$, and $1 \mu \mathrm{M}$ cFP. Increased levels of bioluminescence are observed in 1-2.5 $\mu \mathrm{M}$ before dropping to sub-control levels 


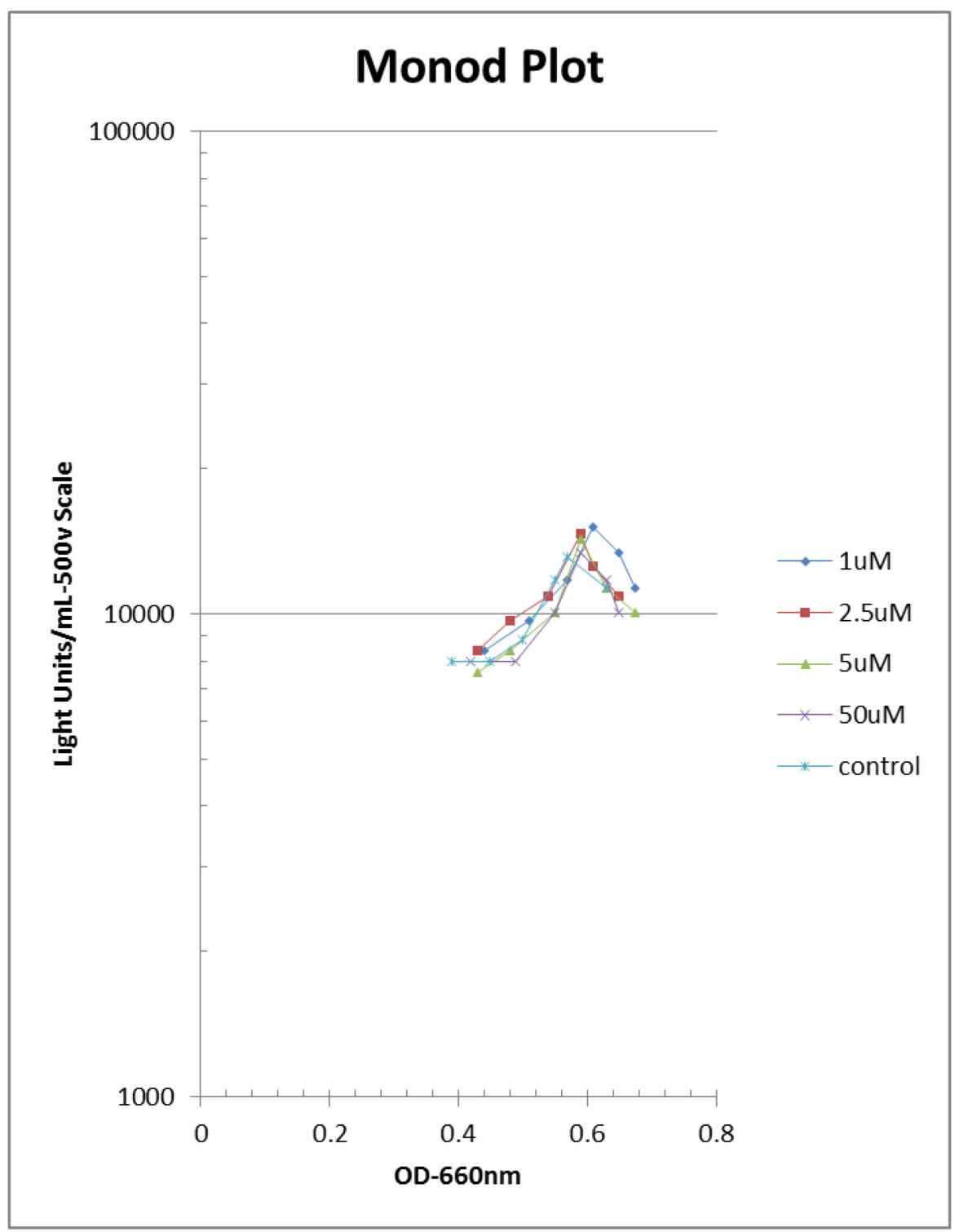

Figure 8. Monod Plot of $V$. harveyi BB886 exposed to $50 \mu \mathrm{M}, 5 \mu \mathrm{M}, 2.5 \mu \mathrm{M}$, and $1 \mu \mathrm{M}$ cFP. Increased levels of bioluminescence are observed in1- $2.5 \mu \mathrm{M}$. 
A

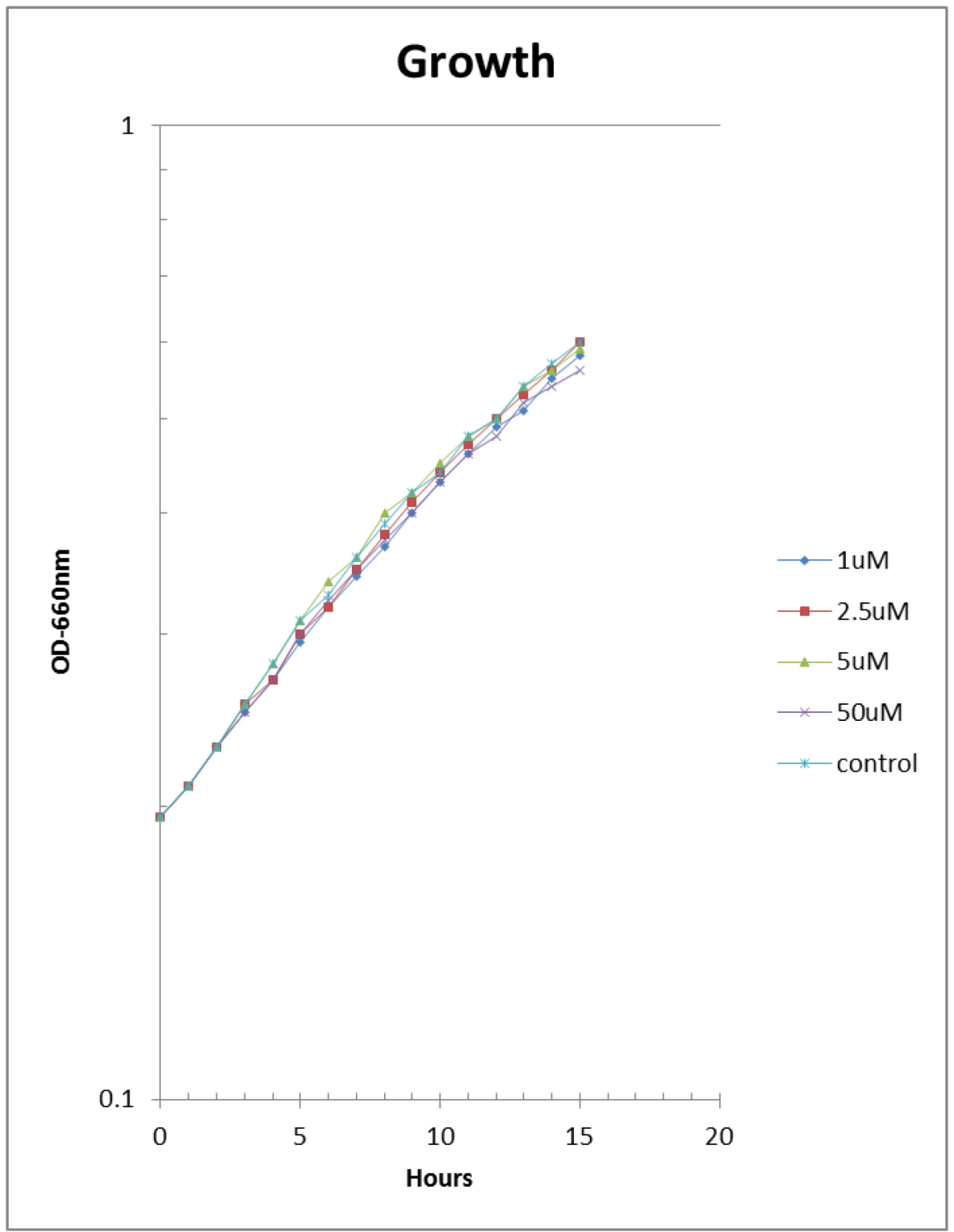

Figure 9. A. Growth curve of $V$. harveyi BB120 in Minimal Media, exposed to $50 \mu \mathrm{M}, 5 \mu \mathrm{M}, 2.5 \mu \mathrm{M}$, and $1 \mu \mathrm{M}$ cFP. Decreased growth rate is observed with higher concentration. 
$\mathrm{B}$

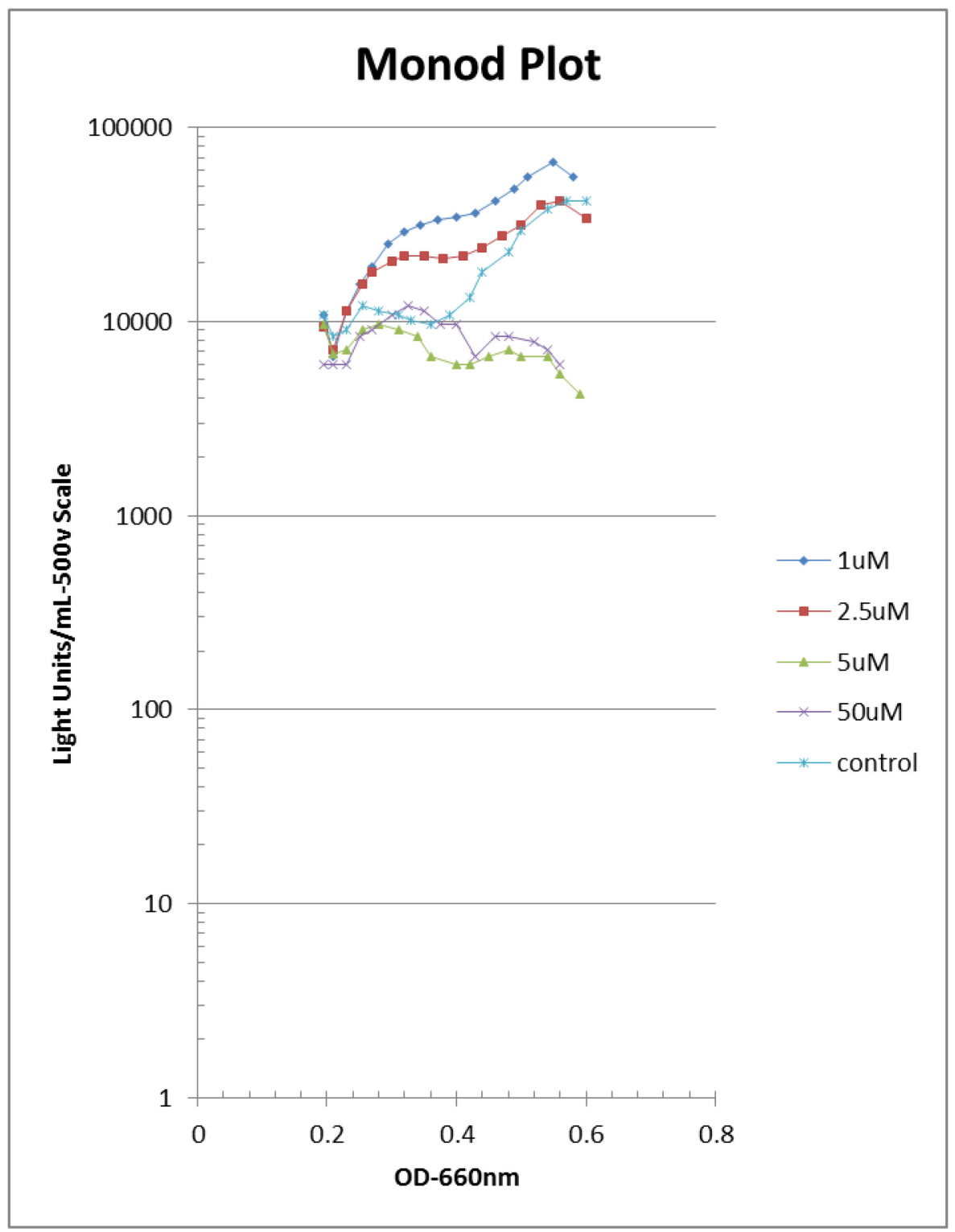

Figure 9. B. Monod Plot of $V$. harveyi BB120 in Minimal Media, exposed to $50 \mu \mathrm{M}, 5 \mu \mathrm{M}, 2.5 \mu \mathrm{M}$, and 1 $\mu \mathrm{M} \mathrm{cFP}$. Increased levels of bioluminescence are observed in 1-2.5 $\mu \mathrm{M}$ before dropping to sub-control levels 


\section{Aim 3: Effect of cFP on Luciferase}

In order to determine whether or not the observed effect of cFP on $V$. harveyi bioluminescence was genuine or just an artifact of the molecule altering the kinetics of the luciferase enzyme the standard luciferase assay was used. The luciferase assay was performed

with three increasing concentrations of $\mathrm{cFP}(5,50$ and $500 \mu \mathrm{M})$ with constant concentrations of the substrates (decanal and $\mathrm{FMNH}_{2}$ ) and luciferase. The average light production of each concentration was not statistically different from the control up to the $500 \mu \mathrm{M}$ (Fig. 10). That means concentrations approaching $500 \mu \mathrm{M}$ and above will have a negative effect on light production by inhibiting luciferase and thereby compromise the notion that cFP affected autoinduction.

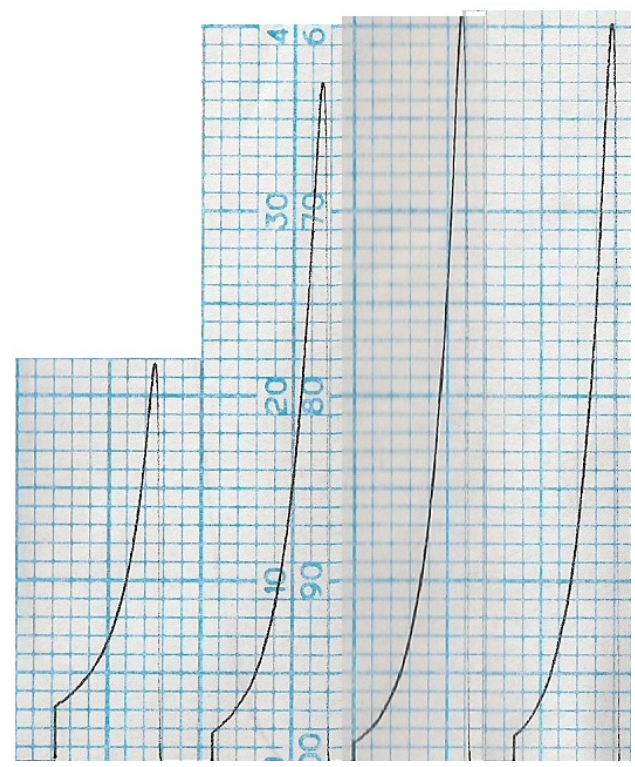

Figure 10- Luciferase Assay. Luciferase Assay: from right to left, each peak was initiated with injection of FMNH2 and then decays over time (one box on the abscissa equals 1 second. The peaks from right to left ( $\mu \mathrm{M} \mathrm{cFP})$ : control, 5,50 , and 500. With decay constants of: $0.621,0.615,0.546$, and 0.364 . 


\section{Discussion}

The lack of increase of the cFP peak found in the mass spectra of $V$. harveyi suggests that the molecule is not produced naturally by $V$. harveyi, whether in $\mathrm{AB}$ or Minimal Media. The peaks present at $\mathrm{m} / \mathrm{z} 245$ may be cFP, but since they were present in the control, it cannot be said to have been produced by $V$. harevyi. This lack of production conflicts with reports from Park et al. (2005) that $V$. harveyi and some related species produced the molecule. The appearance of $\mathrm{cFP}$ in the uninoculated media can be explained by the spontaneous formation of cyclic dipeptides from amino acids upon being autoclaved (Anatol Eberhard 2011, private communication). All of the known $V$. harveyi quorum sensing molecules were detected in the extracts; these are produced and sensed by the same organism.

All of the remaining molecules found by the mass spectrometer in the culture extracts are potential signals in the quorum or other sensing language. They represent what could potentially be a complex signaling language. The molecules present in the extracts of acidic media and absent in the basic could be other HSL's, and even the other molecules which remain in both extracts are potential signaling molecules of a different type.

The metabolic profiles of the Wild-Type strains (MAV and BB120) were the same under exposure to the varying cFP concentrations indicated that $\mathrm{cFP}$ had no effect on $V$. harveyi gene expression concerning metabolism.

Since the effect of cFP on the growth of $V$. harveyi was not significant on any strain in any concentration, it appears not to be involved in any signaling related to growth and that is has no effect on gene expression regulating growth.

The effects of cFP on the bioluminescence of $V$. harvey $i$ were a also weak and not ultimately convincing as a true autoinducer. Even in Minimal media, the effect is small, where if 
the effect was greater, might indicate a quorum sensing signal. The pattern appearing the same for every strain suggests some minimal induction of bioluminescence to occur between 1-5 $\mu \mathrm{M}$ of cFP. An induction of quorum sensing controlled activities agrees with the work of Park et al. (2005) done on $V$. vulnificus. Also as a result of the effect present in every strain, the signaling would have to work outside of the primary two autoinducer systems. Strains BB170 and BB886 are signaling mutants, the first has a mutation in the sensor for AI-1, and the second has a mutation in the sensor for AI-2. Since cFP had the same apparent effect on these two strains as the others, any signaling though quorum sensing would have to operate through a different signal/sensor system. The need to find the signal/sensor system cFP uses does not conflict with the finding by Campbell et al. (2009) that cFP signaling works through LuxR.

The luciferase assay indicated that only at concentrations of cFP approaching $500 \mu \mathrm{M}$ would there be decreased light production. This revealed that the effect of low concentrations of cFP on $V$. harveyi bioluminescence is not an artifact of interaction between the molecule and the luciferase enzyme. Without significant effect of the molecule on the enzyme itself, the effects on light production would have to be caused by a change in quorum sensing signaling. This assay also explains the apparent inhibition of bioluminescence by cFP in higher concentrations, which seems due to an inhibitory effect on the enzyme as opposed to the quorum sensing pathway. Because the assay can explain both ranges of cFP concentration, the apparent discrepancy of effects of the molecule are resolved. However, this does not fully resolve the discrepancy of the effects seen by prior studies, which looked at other quorum sensing controlled activities as well. With the elimination of bioluminescence inhibition from this study, the induction would agree with Park et al (2005), but Bina and Bina (2010) reported quorum sensing inhibition in the same activities as Park et al., and Campbell et al. (2009) has also noticed conflicting reports on the effects of cFP on quorum sensing signaling. 


\section{Conclusion}

This study has shown that the $V$. harveyi strains MAV, BB120, BB170, BB152, and BB886 do not naturally produce the cyclic dipeptide cFP. While these strains were examined for cFP, the potential complexity with which bacteria communicate through quorum sensing was illustrated, with nearly 100 molecules being produced by these five strains cumulatively. This study has also determined some of the effects that the potential quorum sensing signal cFP has on $V$. harveyi. It appears not to have a particularly strong effect on growth, and in concentrations similar to that of known quorum sensing signals cFP might be able to temporarily induce bioluminescence slightly above standard levels. Since, at low concentrations, this effect is not due to an action of cFP on the luciferase enzyme it must function through a signaling pathway. With the effect present in all strains examined, including two quorum sensing sensor mutants (BB170 lacks the sensor of the HA1 signal, BB886 lacks the sensor of the AI2 signal), the signaling must act on a sensor other than the primary two (HAI-1, AI-2).

Overall, the potential quorum sensing molecule cFP does not seem to have any significant effect on or be involved naturally in Vibrio harveyi growth or signaling. Although this study may have helped determine what effects cFP has on $V$. harveyi, its status as a potential true quorum sensing signal amongst the rest of the Vibrio genus and other Gram negative bacteria is still a topic for investigation. 


\section{List of References}

Bina, X.R. and J.E. Bina. (2010). The cyclic dipeptide cyclo(Phe-Pro) inhibits cholera toxin and toxin-coregulated pilus production in $\mathrm{O} 1 \mathrm{El}$ tor Vibrio cholerae. Journal of Bacteriology. 192(14):3829-3832.

Campbell, J. et al. (2009). New and unexpected insights into the modulation of LuxR-type quorum sensing by cyclic dipeptides. ACS Chemical Biology. 4(12):1051-1059.

Centers for Disease Control and Prevention (CDC). (2010). Cholera outbreak --- Haiti, October 2010. MMWR Morb. Mortal Wkly. Rep. 59(43):1411.

Chen, X. et al. (2002). Structural identification of a bacterial quorum-sensing signal containing boron. Nature. 415(6871):545-9.

Davis, B.M. et al. (2010). The interaction of $\mathrm{N}$-acylhomoserine lactone quorum sensing signaling molecules with biological membranes: implications for inter-kingdom signaling. PLoS One. 5(10):e13522.

Haddock, S, M. Moline, and J. Case. (2010). Bioluminescence in the sea. Annual Reviews of Marine Science. 2:443-493.

Hastings, J.W., T.O. Baldwin, and M.Z. Nicoli. (1978). Bacterial luciferase: assay, purification and properties. Methods Enzymol. 57:135-144.

Hastings, J. (1996). Chemistries and colors of bioluminescent reactions: a review. Gene. 173:511.

Henke, J.M. and B.L. Bassler (2004). Three parallel quorum-sensing systems regulate gene expression in Vibrio harveyi. J. Bacteriol. 186(20):6902-14.

Jung, K., T. Odenbach, and M. Timmen. (2007). The quorum-sensing hybrid histidine kinase LuxN of Vibrio harveyi a periplasmic located N terminus. J. Bacteriol. 189(7):29452948.

Kohler, T. et al. (2010). Quorum sensing inhibition selects for virulence and cooperation in Pseudomonas aeruginosa. PLoS Pathog. 6(5):e1000883.

Makemson, J., N.R. Fulayfil, and L.V. Ert. (1998). Differentiation of marine luminous bacteria using commercial identification plates. J. Biolumin. Chemilumin. 13:147-156.

Makemson, J.C. and G.V. Hermosa. (1999). Luminous bacteria cultured from fish guts in the Gulf of Oman. Luminescence. 14(3):161-8.

Makemson, J., A. Eberhard, and K. Mathee. (2005). Simple electrospray mass spectrometry detection of acylhomoserine lactones. Luminescence. 21:1-6.

Meighen, E. (1991, March). Molecular biology of bacterial bioluminescence. Microbiological Reviews. 55(1):123-142. 
Martin, M., and R. Showalter, and M. Silverman. (1989). Identification of a locus controlling expression of luminescence genes in Vibrio harveyi. Journal of Bacteriology. 171(5):2406-2414.

McDougald, D. et al. (2003). Signal-mediated cross-talk regulates stress adaptation in Vibrio species. Microbiology. 149(7):1923-33.

Mitchell, G.W. and J.W. Hastings. (1971). A stable, inexpensive, solid-state photomultiplier photometer. Anal. Biochem. 39(1):243-50.

Mok, K.C., N.S. Wingreen, and B.L. Bassler. (2003). Vibrio harveyi quorum sensing: a coincidence detector for two autoinducers controls gene expression. EMBO Journal. 22(4):870-81.

Nealson, K.H., T. Platt and J.W. Hastings. (1970). Cellular control of the synthesis and activity of the bacterial luminescent system. J. Bacteriol. 104(1):313-22.

Nijvipakul, S. et al. (2008). LuxG is a functioning flavin reductase for bacterial luminescence. J. Bacteriol. 190(5):1531-1538.

Park, D.K. et al. (2006). Cyclo(Phe-Pro) modulates the expression of ompU in Vibrio spp. J. Bacteriol. 188(6):2214-2221.

Qin, N. et al. (2007). Analysis of LuxR regulon gene expression during quorum sensing in Vibrio fischeri. J. Bacteriol. 189(11):4127-4134.

Shimomura, O., F. Johnson, and Y. Kohama. (1972) Reactions involved in bioluminescent systems of limpet (Latia neritodes) and luminous bacteria. Proc. Nat. Acad. Sci. 6(8):2086-2089.

Shen, F. et al. (2010). In Heliobacter pylori auto-inducer-2, but not LuxS/MccAB catalysed reverse transsulphuration, regulates motility through modulation of flagellar gene transcription. BMC Microbiol. 10(210).

Widder, E.A. (2010). Bioluminescence in the ocean: origins of biological, chemical, and ecological diversity. Science. 328:704-708.

Wimpee, C.F., T.L. Nadeau, and K.H. Nealson. (1991). Development of species-specific hybridization probes for marine luminous bacteria by using in vitro DNA amplification. Appl. Environ. Microbiol. 57(5):1319-24. 


\section{Appendices}

\section{Appendix 1}

\section{Table of Extractable Molecules Produced by Vibrio harveyi}

\begin{tabular}{|c|c|c|c|c|c|c|c|c|c|c|c|}
\hline $\mathrm{m} / \mathrm{z}$ & & $\mathrm{MAV} / \mathrm{H}$ & $\mathrm{MAV} / \mathrm{OH}$ & $120 / \mathrm{H}$ & $120 / \mathrm{OH}$ & $170 / \mathrm{H}$ & $170 / \mathrm{OH}$ & $152 / \mathrm{H}$ & $152 / \mathrm{OH}$ & $886 / \mathrm{H}$ & $886 / \mathrm{OH}$ \\
\hline & & & & & & & & & & & \\
\hline 105.0 & & & & & & & & & $x$ & & \\
\hline 114.0 & & & & & & & & & & $x$ & \\
\hline 120 & & & & & & & & & $x$ & & \\
\hline 121.0 & & & & & $x$ & & & & & & \\
\hline 122.0 & & & & & & & & & $x$ & & \\
\hline 123.3 & & & & $x$ & $x$ & & & & & & \\
\hline 123.9 & & & & & & & $x$ & & & & \\
\hline 124.9 & & & $x$ & & & & & & & & \\
\hline 126.9 & & $x$ & & & & & & & & & \\
\hline 130 & & & & & & $x$ & & & & & \\
\hline 133 & & & & & & & $x$ & & $x$ & & \\
\hline 134 & & & & & & & $x$ & & & & \\
\hline 135.3 & & & & & & & & & $x$ & & \\
\hline 136.2 & & & & & $x$ & & & & & & \\
\hline 137.1 & & & & & & & $x$ & & $x$ & & \\
\hline 139.0 & & & $x$ & & $x$ & & $x$ & & & & \\
\hline 141.3 & & $x$ & & & & & & $\mathrm{x}$ & & & \\
\hline 143 & & & & & & & $x$ & & & & \\
\hline 144.0 & & & & & & & $x$ & & $x$ & & $x$ \\
\hline 145.0 & & & & & & & & & $x$ & & $x$ \\
\hline 145.6 & & & $x$ & & & & $x$ & & $x$ & & \\
\hline 146 & & & & & & & & & & & $x$ \\
\hline 147.0 & & & & & & & $x$ & & & & $x$ \\
\hline 149.1 & & & & & & & & & & & $x$ \\
\hline 150.2 & & & & & $x$ & & & & & & \\
\hline 151.2 & & & & & & & & & & & $x$ \\
\hline 155.3 & & & & & & & $x$ & & & & \\
\hline 157 & & & & $x$ & & & & & & & \\
\hline 159.1 & & & $x$ & & & & & & & & \\
\hline 160.1 & & & & & & & & & & $\mathrm{x}$ & \\
\hline 163.3 & & & & & & & & & & $x$ & \\
\hline 165.4 & & & & & $x$ & & & & & & \\
\hline 172.4 & & $x$ & & $x$ & & $x$ & & $\mathrm{x}$ & & & \\
\hline 176.3 & & & $x$ & & & & & & & & \\
\hline 185.0 & & & & & & & $x$ & $x$ & $x$ & & $x$ \\
\hline 186.0 & $\mathrm{Al}-1$ & $x$ & & $x$ & & $x$ & & & & $x$ & \\
\hline 193.0 & $\mathrm{Al}-2 \mathrm{P}$ & & & & & $x$ & & & & $x$ & \\
\hline 194 & $\mathrm{Al}-2 \mathrm{P}$ & $x$ & & & & & & & & & \\
\hline 195.2 & $\mathrm{Al}-2 \mathrm{P}$ & & $x$ & $x$ & & & & & & & $x$ \\
\hline 196 & & & $x$ & & & & & & & & \\
\hline 200.1 & & & & & & & $x$ & & & & \\
\hline 202.2 & & $x$ & & $x$ & & $x$ & & & & & \\
\hline 203.1 & & & $\mathrm{x}$ & & & & & $x$ & & $\mathrm{x}$ & \\
\hline 207 & & & & & & & $x$ & & & & \\
\hline 211.1 & & & & & & & & & & $x$ & $x$ \\
\hline 211.9 & CA-1 & $x$ & & & & & & & & & \\
\hline
\end{tabular}




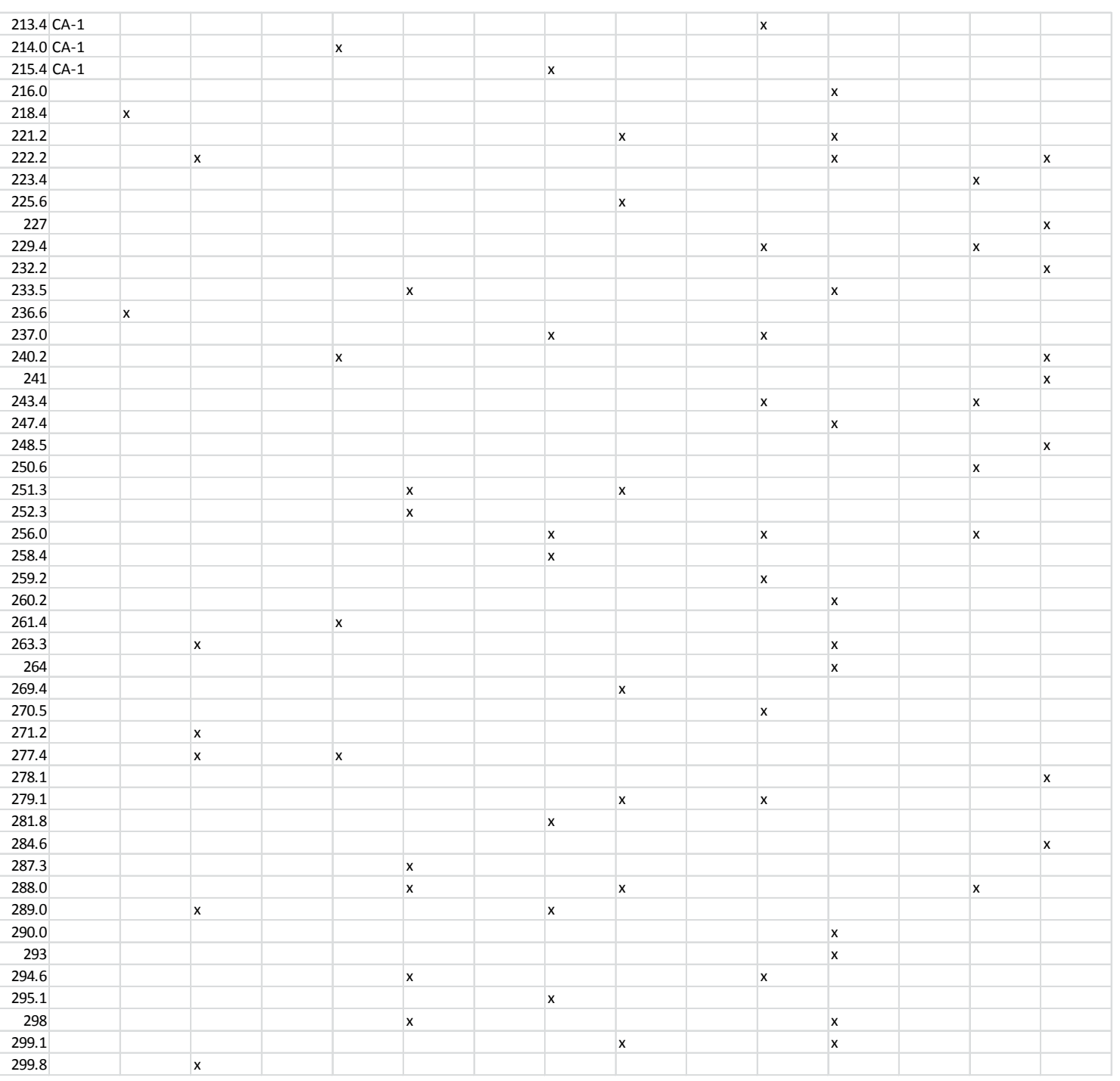

Table of Extractable Molecules Produced by Vibrio harveyi. Molecules that are produced by $V$. harveyi and detected from extracts of both acidified and alkalinized cell-free cultures by Electrospray Mass Spectrometry from $V$. harveyi strains MAV, BB120, BB170, BB152, and BB886. 